\title{
Augmentation of Freshwater Productivity in a Single Slope Solar Still Using Ball Marbles
}

\section{Subbarama Kousik Suraparaju}

NIT Puducherry: National Institute of Technology Puducherry

\section{Dhivagar Ramasamy}

QISCET: QIS College of Engineering and Technology

SENDHIL KUMAR NATARAJAN ( $\nabla$ drsendhil1980iitmuk@gmail.com )

National Institute of Technology Puducherry https://orcid.org/0000-0003-3257-4570

\section{Research Article}

Keywords: Solar Desalination, Solar Still, Sensible Heat, Ball marbles, Economic Analysis

Posted Date: April 30th, 2021

DOI: https://doi.org/10.21203/rs.3.rs-420418/v1

License: (c) (1) This work is licensed under a Creative Commons Attribution 4.0 International License.

Read Full License

Version of Record: A version of this preprint was published at Environmental Science and Pollution Research on July 29th, 2021. See the published version at https://doi.org/10.1007/s11356-021-15117-5. 

Pradesh - 523272, India. 
10 In the current research, the energy and economic performance in single slope solar still using ball marbles (BMSS)

11 has been investigated and compared the results with conventional solar still (CSS) under the similar weather conditions of Karaikal $\left(10.92^{\circ} \mathrm{N}, 79.83^{\circ} \mathrm{E}\right)$, India during October 2020 . The experiments have been conducted on

13 both sunny and cloudy day to evaluate the performance of solar still. The BMSS has increased the evaporation rate and productivity when compared to CSS due to the sensible heat energy stored by the ball marbles in the absorber basin. The potable water yield of the BMSS is improved by $21.23 \%$ and $22.86 \%$, respectively during sunny and cloudy days. The maximum cumulative productivity obtained in the BMSS is $2950 \mathrm{ml} / \mathrm{m}^{2}$. day and $2150 \mathrm{ml} / \mathrm{m}^{2}$. day respectively on sunny and cloudy days. In economic analysis, the payback period (PBP) of the BMSS is 5.7 months whereas the PBP of the CSS is 6.5 months respectively. Furthermore, the cost per litre (CPL) potable water produced by BMSS is $8 \%$ lower than the CPL of CSS.

Keywords: Solar Desalination; Solar Still; Sensible Heat; Ball marbles; Economic Analysis.

\section{Introduction}

Drinking water and energy are the two crucial needs required to survive on Earth. Owing to the exponential growth in the population around the world, the abundance of freshwater is rapidly increasing day by day. The supply of freshwater is also affected by the rapid rise in industrialization and agricultural practises across the globe. The scarcity of freshwater is also leading to various health problems which adversely affect people's economic prosperity (UN World Water Development Report 2020) The potential way of solving this freshwater crisis is through various desalination approaches by converting the available seawater into drinking water. Solar still is considered as one of the best ways to desalinate seawater effectively and economically. Solar Still is eco-friendly and economical in such a way that everyone can easily implement it for seawater desalination (Arjunan et al. 2009; Aybar and Assefi 2009; Manchanda and Kumar 2015; Sharon and Reddy 2015; Dsilva Winfred Rufuss et al. 2016). Nevertheless, the solar still efficiency is comparatively lower than other approaches and many researchers are working to boost solar efficiency through various design improvements and incorporations into the still such as fins/energy storage (Muthu Manokar et al. 2014; Durkaieswaran and Murugavel 2015; El-Sebaii and El-Bialy 2015; Yadav and Sudhakar 2015; Bait and Si-Ameur 2018; Selvaraj and Natarajan 2018; Dhivagar and Sundararaj 2018).

In this aspect, Kumar and Tiwari evaluated the internal heat transfer coefficients of solar stills by utilizing various thermal models. It was found that the Kumar and Tiwari Model (KTM) validated the results better when compared with other models. The internal heat transfer coefficients of passive and active solar stills were found to be 0.78 
and $2.41 \mathrm{~W} / \mathrm{m}^{2} . \mathrm{K}$ (Kumar and Tiwari 2009). Khalifa and Mahamood evaluated the influence of brine water depth on the freshwater yield of solar still. It was seen that the water depth of the solar still influenced productivity by 48\% (Khalifa and Hamood 2009). Tanaka and Nakatake analysed the performance of tilted wick solar still theoretically with an inclined flat reflector that attached externally to the system. It was inferred that the yield of solar still was increased by $15 \%$ and $27 \%$ when the length of the reflector was half and the same of the solar still respectively (Tanaka and Nakatake 2009). Sakthivel et al. studied the regenerative type solar still with jute cloth for better productivity. It was found that the modified solar still had an increase in the yield by $20 \%$ and efficiency was improved by $8 \%$ compared to CSS (Sakthivel et al. 2010). Dashtban and Tabrizi analysed the performance of solar still with paraffin wax for better yield. It was found from the theoretical analysis, the PCM based solar still achieved 31\% higher productivity compared to CSS (Dashtban and Tabrizi 2011). Arunkumar et al. studied the significance of PCM on the yield of solar still. It was found that the inclusion of PCM enhanced the distillate yield by $26 \%$ when compared to CSS (Arunkumar et al. 2013). Ziabari et al. assessed the cascade type of solar stills. It was found that the cascade solar still achieved $6.7 \mathrm{~L} / \mathrm{m}^{2}$ which was $26 \%$ higher than the CSS (Ziabari et al. 2013). Gad et al. studied the performance of conical type solar still for enhancement of productivity. It was found that the conical solar still attained a yield of $3.38 \mathrm{~L} / \mathrm{m}^{2}$ whereas the CSS attained only $1.93 \mathrm{~L} / \mathrm{m}^{2}$ (Gad et al. 2015). Panchal et al. examined the effect of sandstones and marble pieces on the yield of solar still. It was observed that the solar still with sandstones achieved better yield than the marble pieces and a conventional one (Panchal et al. 2017). Shalaby et al. studied the working of solar still with wax and wicks for better productivity. It was observed that the solar still with PCM achieved a $12 \%$ and $11.7 \%$ increase in productivity when compared to setup without PCM and setup with PCM using wick material respectively (Shalaby et al. 2016). Sahota and Tiwari studied the impact of $\mathrm{Al}_{2} \mathrm{O}_{3}$ nanoparticles on the yield of solar still with $35 \mathrm{~kg}$ and $80 \mathrm{~kg}$ water depth. It was noticed that the yield of solar still with $0.12 \%$ concentration of $\mathrm{Al}_{2} \mathrm{O}_{3}$ nanoparticles enhanced by $12.2 \%$ and $8.4 \%$ for $35 \mathrm{~kg}$ and $80 \mathrm{~kg}$ water depth respectively when compared to CSS (Sahota and Tiwari 2016). Singh et al. estimated the life cycle cost analysis of passive solar stills. It was observed that the kW $\mathrm{h}$ per unit cost based on the analysis for a single slope and double slope passive solar stills was about $0.144 \mathrm{~kW}$ $\mathrm{h} / ₹$. and $0.137 \mathrm{~kW} \mathrm{h/₹} \mathrm{respectively.} \mathrm{It} \mathrm{was} \mathrm{concluded} \mathrm{from} \mathrm{the} \mathrm{analysis} \mathrm{that} \mathrm{the} \mathrm{single} \mathrm{slope} \mathrm{passive} \mathrm{solar} \mathrm{still}$ performs better than the double slope setup (Singh et al. 2016). Kabeel and Abdelgaid analysed solar still with parabolic concentrator and energy storage for better productivity. It was inferred from the experimental investigation, the yield of modified solar still was improved by $140.4 \%$ when compared to CSS (Kabeel and Abdelgaied 2017). Fathy et al. examined the performance of double slope 
solar still with parabolic trough concentrator system for augmenting the freshwater productivity. It was observed from the results that the solar with tracking concentrator had an improvement in the yield by $28.1 \%$ when compared with fixed concentrator coupled solar still. Also, the solar still with tracking concentrator had an increase in productivity by $142.3 \%$ when compared to CSS (Fathy et al. 2018). Rufuss et al. studied the nanoparticles enhanced PCM (NPCM) in solar still for better productivity. It was found that there was an increase of 35\% yield in the solar still with NPCM compared to the solar still with PCM (Winfred Rufuss et al. 2017). Chamkha et al. investigated the influence of Carbon Nano Tubes doped paraffin wax on the performance of solar still. It was observed that the hybrid PCM had an enhancement in productivity by $41.4 \%$ and $26.4 \%$ compared to CSS and virgin PCM (Chamkha et al. 2020). Kabeel et al. investigated the influence of sand wrapped in a jute cloth as sensible heat energy storage on the solar still. It was observed that the modified still attained the yield of $5.9 \mathrm{~kg} / \mathrm{m}^{2}$ whereas the conventional still achieved only $5 \mathrm{~kg} / \mathrm{m}^{2}$. Kabeel et al. studied different PCMs for augmenting the productivity of the solar still. It was inferred that the capric-palmitic and PCM A48 had better advantages compared to other PCMs considered in terms of high yield and low cost. Also, found that the thickness of PCM used had no significant effect on the yield (Kabeel et al. 2018a) (Kabeel et al. 2018b). Manokar et al. studied the inclined solar panel basin still in both passive and active modes for enhancement of yield. It was noticed that the active solar still had an increase in freshwater productivity by $44.63 \%$ compared to the passive solar still (Manokar et al. 2018). Sathyamurthy and El-Agouz studied the effect of Fresnel lens and blue stones on the performance of solar still. The solar with Fresnel lens and with blue stones achieved 26.64\% and 35.55\% better yield compared to CSS (Sathyamurthy and El-Agouz 2019). Satish Kumar et al. analysed the performance of fin-type solar still with energy storage media (ESM). It was found that the efficiency was increased by $64 \%$ and $94 \%$ in solar still with fins alone and solar still with fins cum ESM respectively when compared with the conventional setup (Sathish Kumar et al. 2019).

Dhivagar and Sundararaj studied the effect of copper tube heat exchanger in coarse aggregate on the productivity of solar still. It was found that the efficiency was improved by $17 \%$ in the modified still compared to CSS (Dhivagar and Sundararaj 2019). Dhivagar et al. investigated the gravel coarse aggregate as energy storage in the solar still for better productivity. It was found that the yield of modified solar still was about $4.21 \mathrm{~kg} / \mathrm{m}^{2}$ (Dhivagar et al. 2020). Sakthivel and Arjunan evaluated solar still with cotton cloth as an energy storage medium. It was noticed that the productivity of modified solar still was increased by $24.1 \%$ when compared with traditional solar still without energy storage (Sakthivel and Arjunan 2019). Vigneswaran et al. investigated the effect of multiple 
$100 \mathrm{~L} / \mathrm{m}^{2} /$ day (Vigneswaran et al. 2019). Dumka et al. investigated the effect of sand filled cotton bags on the

101 productivity of solar still. It was seen that the yield of modified solar still was increased by $28.56 \%$ and $30.99 \%$

102 when compared with traditional still at $30 \mathrm{~kg}$ and $40 \mathrm{~kg}$ basin water (Dumka et al. 2019). Raj et al. evaluated the

103 influence of metal chips, sandstones and calcium oxide as heat energy storage on the solar desalination system. It

104 was noticed that the solar still with calcium oxide had a $26.98 \%$ improvement in the yield when compared to CSS

105 (Raj et al. 2020). Patel et al. investigated the double solar still with reflectors for producing the drinking water

106 from the feed water of Gomti river, India. It was found that there was an increase in the yield by $10.4 \%$ and $10.0 \%$

107 during summer and winter respectively with a reflector at an angle of $60^{\circ}$ (Patel et al. 2020). Suraparaju and

108 Natarajan studied the impact of the ridge gourd natural fibres on the performance of the single-slope solar still. It

109 was depicted that the more number of natural fibres in the absorber reduced the performance of solar still

110 (Suraparaju and Natarajan 2020). Dumka et al. studied the influence of jute covered plastic balls on the

111 productivity of solar still. It was found that there was an increase in the yield by $64 \%$ when compared to

112 conventional still (Dumka et al. 2020)

113 Based on the above literature, it can be outlined that many researchers utilized various approaches like energy

114 storage materials (sensible heat \& latent heat), surface enhancers such as fins and wicks in the basin for improving

115 the freshwater productivity of solar still. It was found that there was no particular extensive research on ball

116 marbles as a sensible heat energy storage medium in the solar still basin. In this aspect, the current research aims

117 to investigate the inclusion of the ball marbles into the solar still for enhancing freshwater productivity. Hence,

118 the experiments are conducted with ball marble solar still (BMSS) and compared the productivity improvements

119 with conventional solar still (CSS). The cost-effectiveness of both the solar stills is estimated using economic 120 analysis.

\section{2. Materials and Experimentation}

122 The experiments are carried out with BMSS and CSS at the NIT Puducherry $\left(10.92^{\circ} \mathrm{N}, 79.83^{\circ} \mathrm{E}\right)$, Karaikal, India 123 during the sunny and cloudy days of October 2020.

\section{2.1. System Description}

125 In the present investigation, two similar single-slope solar stills are designed and fabricated to examine the effect

126 of ball marbles on the improvement of freshwater productivity in the solar still. The two solar stills that have been 127 developed for analysis are as follows:

128 1. Conventional Solar Still (CSS) 


\subsection{Materials and Fabrication}

131 The two solar stills are made of durable plywood and the internal structure of the solar still has an aluminium 132 layer of $2 \mathrm{~mm}$ thickness, which restricts the direct interaction between water vapour and plywood. Also, the 133 aluminium sheet is coated with standard black paint for absorbing more solar radiation into the system. The 134 absorber basin is made of a $1 \mathrm{~mm}$ copper sheet, and the dimensions of the absorber basin are $1000 \mathrm{~mm} \times 600 \mathrm{~mm}$ $\times 50 \mathrm{~mm}\left(0.6 \mathrm{~m}^{2}\right.$ absorber area). The solar still is covered with a transparent and the glass cover is fixed at an angle equal to the latitude of Karaikal for the efficient operation of the system (Singh and Tiwari 2004). The absorber basins of CSS and BMSS are filled with seawater at a particular depth. The black coated marble balls of $25 \mathrm{~mm}$ diameter are introduced into the absorber basin of BMSS. The entire absorber area is equipped with black coated marbles to study the impact on the productivity of solar still. The complete outer area of the solar still is insulated with $2 \mathrm{~cm}$ thick Thermocol sheets to reduce the heat losses from the system. The photograph of the BMSS and CSS is depicted in Fig. 1.

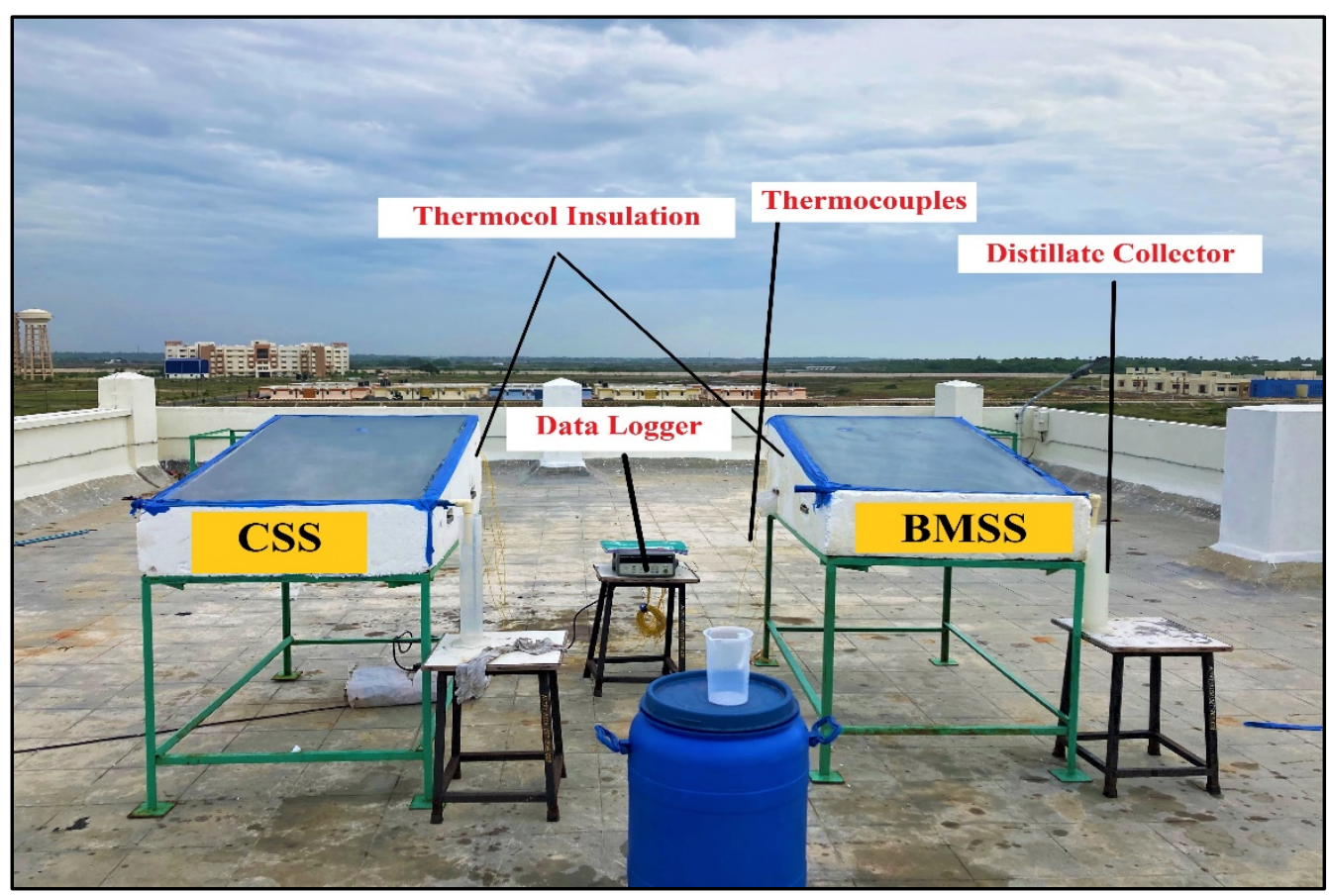

Fig. 1 Photographs of BMSS and CSS

\section{2.3. Preparation of Black Coated Ball Marbles}

145 The study is mainly focused on the use of black-coated ball marbles for augmenting the freshwater production

146 from the solar still. The ball marbles are commercially available in the market and procured from the market for experimental investigation. The marble balls are coated with selective black paint (Thurmalox ${ }^{\circledR}$ ) for better absorption of incident global solar radiation. The arrangement of ball marbles in the solar still basin is shown in 
149 Fig. 2. The ball marbles have a specific heat capacity of about $850 \mathrm{~J} / \mathrm{kg} .{ }^{\circ} \mathrm{C}$ which stores and releases the heat

150 energy at the desired temperatures required for operating the solar still with energy storage. Hence, the black-

151 coated ball marbles are chosen for the experimental investigation in the current research.

152

153

154

155

156

157

158

159

160

161

162

163

164

165

166

167

\subsection{Experimentation}

The performance investigation of single slope solar still with and without black coated marble balls is carried out on a sunny day and cloudy day of October 2020 to study the effect of marble balls on freshwater productivity. The feed water for this investigation is collected from the Bay of Bengal sea located adjacent to the NIT Puducherry. The seawater in the absorber basin is filled to a depth of $2 \mathrm{~cm}$ and maintained constant throughout the investigation by adding makeup water at regular intervals. The temperatures of the glass cover, seawater, absorber basin, marble balls and ambient temperature are measured using calibrated $\mathrm{K}$ - type thermocouples connected to the Data acquisition system (Agilent 34972A ). The global radiation of the particular testing day at the testing location is measured using the "Hukseflux Pyranometer". The experiments are conducted on 14.10.2020 (cloudy day) and 15.10.2020 (sunny day), respectively. The readings are recorded from 08:00 am to 06:00 pm (Indian Standard Time) for every half an hour.

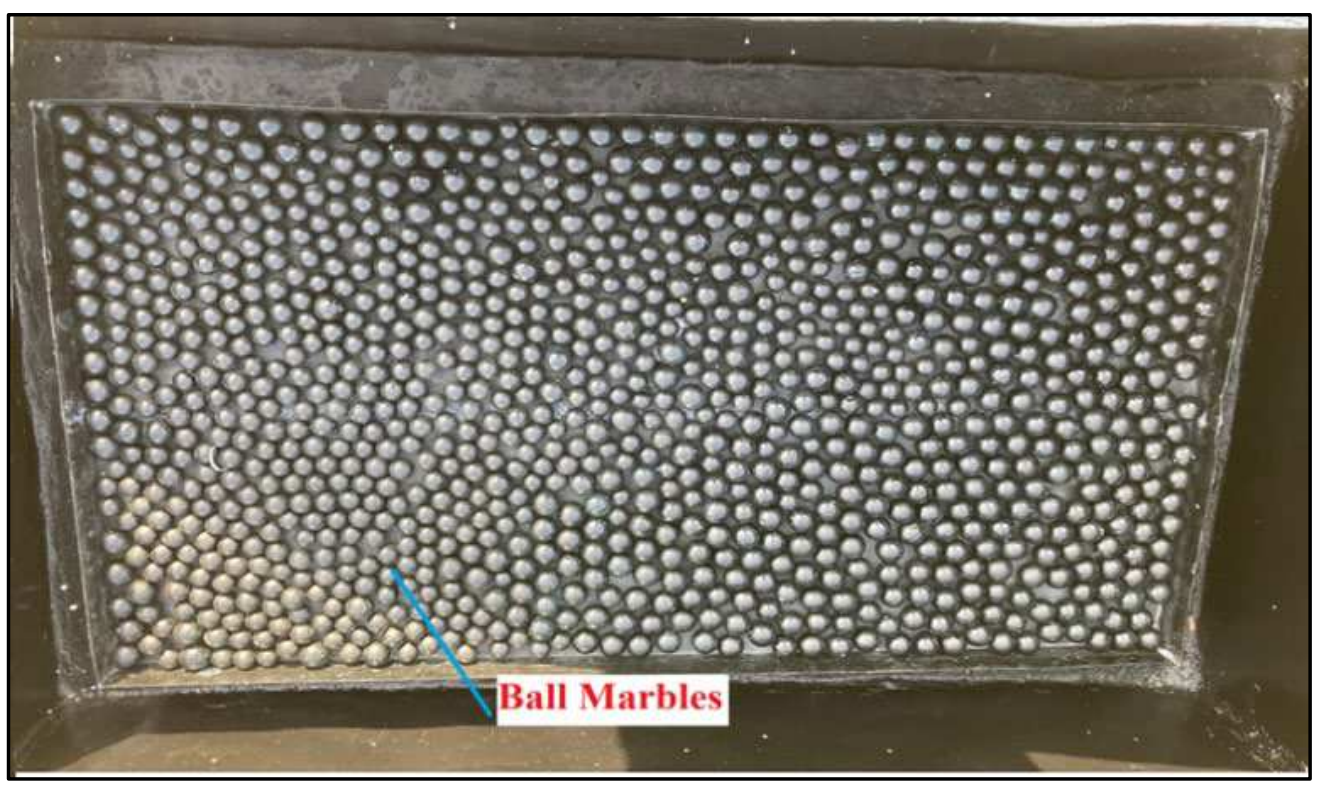

Fig. 2 Arrangement of black coated ball marbles in the solar still

\section{Uncertainty Analysis}

The uncertainties in measuring instruments are estimated using the following relations (J. P. Holman 2007)

$w_{r}=\left[\left(\frac{\partial R}{\partial x_{1}} w_{1}\right)^{2}+\left(\frac{\partial R}{\partial x_{2}} w_{2}\right)^{2}+\cdots \ldots \ldots+\left(\frac{\partial R}{\partial x_{n}} w_{n}\right)^{2}\right]^{1 / 2}$ 

variable with respect to the uncertainty. The uncertainty of the thermocouple, pyranometer, and measuring cylindrical jar used in the experimental investigation is tabulated in Table 1.

Table 1 Uncertainties of the Instruments

\begin{tabular}{|c|c|c|c|c|}
\hline S. No & Apparatus & Range & Accuracy & uncertainty \\
\hline 1 & Thermocouple - K type & -270 to $1,260^{\circ} \mathrm{C}$ & $\pm 0.1^{\circ} \mathrm{C}$ & $0.058^{\circ} \mathrm{C}$ \\
\hline 2 & Pyranometer & 0 to $1600 \mathrm{~W} / \mathrm{m}^{2}$ & $\pm 10 \mathrm{~W} / \mathrm{m}^{2}$ & $5.774 \mathrm{~W} / \mathrm{m}^{2}$ \\
\hline 3 & Measuring Cylinder & 0 to $1000 \mathrm{ml}$ & $\pm 10 \mathrm{ml}$ & $5.774 \mathrm{ml}$ \\
\hline
\end{tabular}

173 Natarajan 2021)

$u_{\eta}=\left[\left(\frac{\partial \eta_{d}}{d_{w}} \times u_{d_{w}}\right)^{2}+\left(\frac{\partial \eta_{d}}{I(t)} \times u_{I(t)}\right)^{2}\right]^{\frac{1}{2}}$

175 It was assessed that the error in total potable water yield is $\pm 1.5 \%$. In addition to that, the error in global radiation

176 and temperature measurement is $0.05 \%$ and $0.1 \%$. Hence, the total error is about $\pm 2 \%$

\section{Energy and Economic Analysis}

178 The thermal efficiency of the passive solar still is evaluated by using the following formula (Kabeel and

179 Abdelgaied 2016)

$180 \quad \eta_{t h}=\frac{P . Y \times \lambda}{A_{b} \times G R \times \Delta t}$

181 where P.Y is the overall potable water yield, $\lambda$ is the latent heat of evaporation of water, $A_{b}$ is the absorber basin

182 area in, $\mathrm{G}$ is daily overall incident global solar radiation and $\Delta \mathrm{t}$ is the duration of the cumulative readings in sec.

183 Here, $\lambda=3.1615 \times\left(10^{6}-761.6 * T_{a}\right)$, if $T_{a}>70$,

184 Else, $\lambda=2.4935 \times\left(10^{6}-947.79 * T_{a}+0.13132 * T_{a}{ }^{2}-0.0047974 * T_{a}{ }^{3}\right)$,

$185 T_{a}=\frac{T_{\text {water }}+T_{\text {glass }}}{2}$

\subsection{Economic Analysis}

187 The economic viability of solar stills is evaluated using the following relations (Esfahani et al. 2011)

$188 \quad \mathrm{FAC}=\mathrm{CRF} \times \mathrm{CC}$

$189 \quad \operatorname{CRF}=\frac{\mathrm{i}(1+\mathrm{i})^{\mathrm{n}}}{(1+\mathrm{i})^{\mathrm{n}}-1}$

$190 \quad$ ASV $=\mathrm{SSF} \times \mathrm{S}$

$191 \mathrm{~S}=0.2 \times \mathrm{CC}$ 
$192 \quad \mathrm{SFF}=\frac{\mathrm{i}}{(1+\mathrm{i})^{\mathrm{n}}-1}$

$193 \quad \mathrm{AMC}=0.15 \times \mathrm{FAC}$

$194 \mathrm{AC}=\mathrm{FAC}+\mathrm{AMC}-\mathrm{ASV}$

$195 \mathrm{CPL}=\frac{\mathrm{AC}}{\mathrm{P}_{\mathrm{d}}}$

$196 \quad$ PBP $=\frac{\text { Investments }}{\text { Net earnings }}$

197 Net Earnings $=$ Market water price $\left(\right.$ per L) $\times$ Productivity $(\mathrm{L}) /$ day $^{2}$

198 Here, the interest rate (i) is $10 \%$ and the lifetime (n) of the solar stills (BMSS \&CSS) 10 years. The operating days

199 of solar still are considered as 270 days in a year.

200 5. Results \& Discussion

201 The experimentations have been carried out in both BMSS and CSS during the sunny and cloudy days of October 2022020 to assess the performance. The results observed in BMSS is compared with CSS under the same climate 203 conditions.

204 5.1. Experimental observation

205 The variations of solar irradiation and ambient temperature in both days are illustrated in Fig. 3. On sunny and 206 cloudy days, during morning hours, the solar irradiation was gradually increasing and attained a higher value of 207 about $1052.63 \mathrm{~W} / \mathrm{m}^{2}$ and $983.38 \mathrm{~W} / \mathrm{m}^{2}$, respectively. In between, the formation of clouds was reducing the length 208 of sun shines considerably. Hence, during evening hours, the intensity of solar irradiation was reduced slowly and 209 reached to lesser value of about $27 \mathrm{~W} / \mathrm{m}^{2}$. It was noticed that, during afternoon hours, the maximum ambient 210 temperatures were about $35.2^{\circ} \mathrm{C}$ on both testing days. During evening time, it was reduced to about $27.6^{\circ} \mathrm{C}$ and $21125.2{ }^{\circ} \mathrm{C}$, respectively for a sunny day and cloudy day. The phenomenon was due to the reduction in the intensity

212 of solar irradiation. The variations of wind velocity on both days are illustrated in Fig. 4. The wind velocity played

213 a major role during the condensation of water vapour at the bottom of the glass cover. The wind velocity was

214 changing in the range between $1.6 \mathrm{~m} / \mathrm{s}$ and $5.1 \mathrm{~m} / \mathrm{s}$ during the experimentation. 


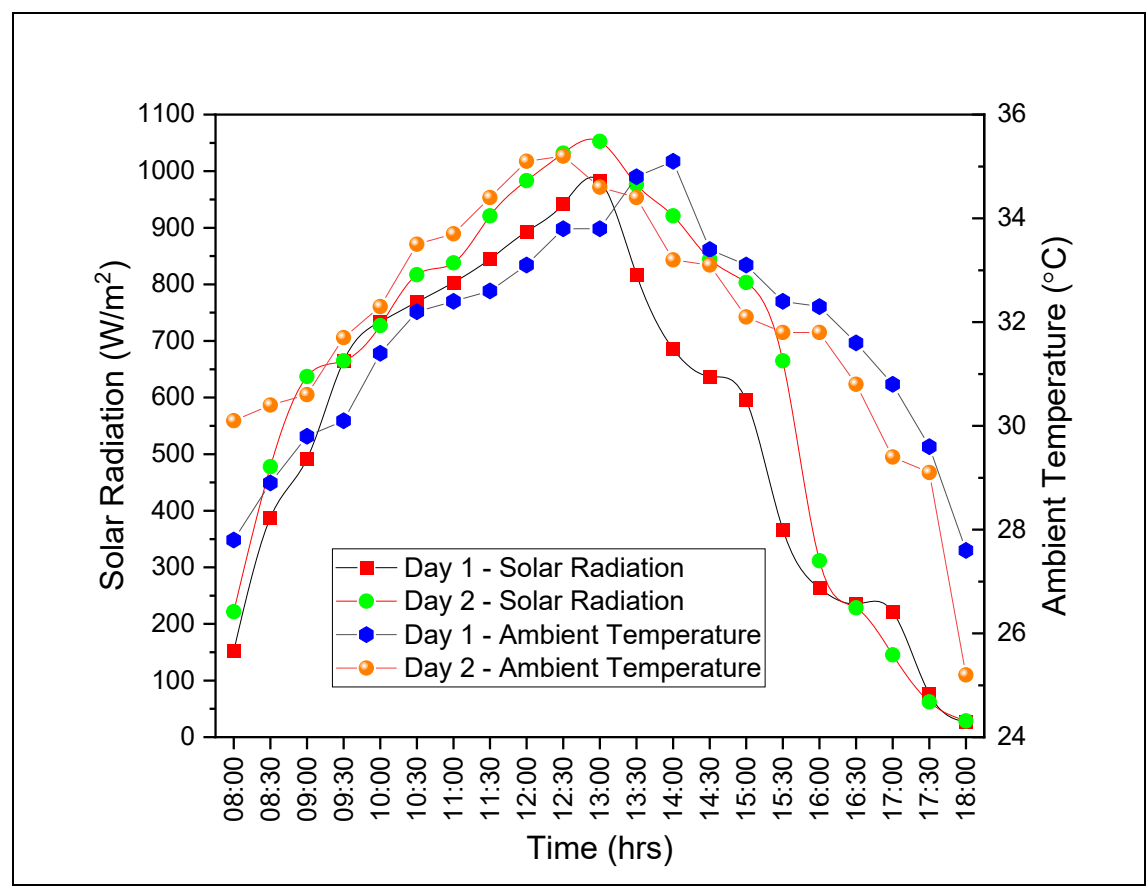

Fig. 3 Variations of solar radiation and ambient temperature with time

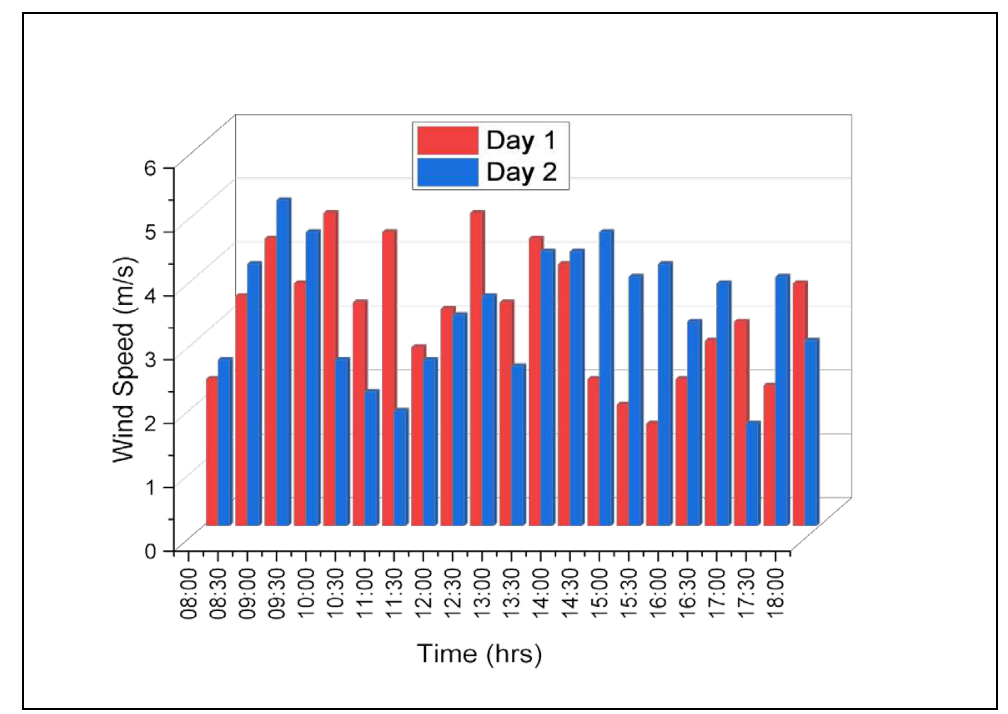

Fig. 4 Variations of wind velocity with time

219 The variations of different temperatures of both BMSS and CSS on day 1 are illustrated in Fig. 5. It was noticed

220 that the maximum glass temperature of BMSS and CSS were about $57.7^{\circ} \mathrm{C}$ and $56.8^{\circ} \mathrm{C}$, respectively and, it was

221 reduced to about $36.5^{\circ} \mathrm{C}$ and $30.8^{\circ} \mathrm{C}$, respectively. The maximum absorber basin temperatures of BMSS and

222 CSS were reported as $64.2{ }^{\circ} \mathrm{C}$ and $58.1{ }^{\circ} \mathrm{C}$ respectively. It was observed that the absorber temperature of BMSS

223 was about $10 \%$ higher than CSS. Along with the absorber, the maximum ball marbles temperature was recorded

224 as $69.9^{\circ} \mathrm{C}$ in BMSS. Furthermore, it was observed that the maximum water temperature in BMSS and CSS was

$22563.1^{\circ} \mathrm{C}$ and $56.8^{\circ} \mathrm{C}$, respectively. The water temperature was improved significantly in BMSS due to the impact 

water temperature of CSS.

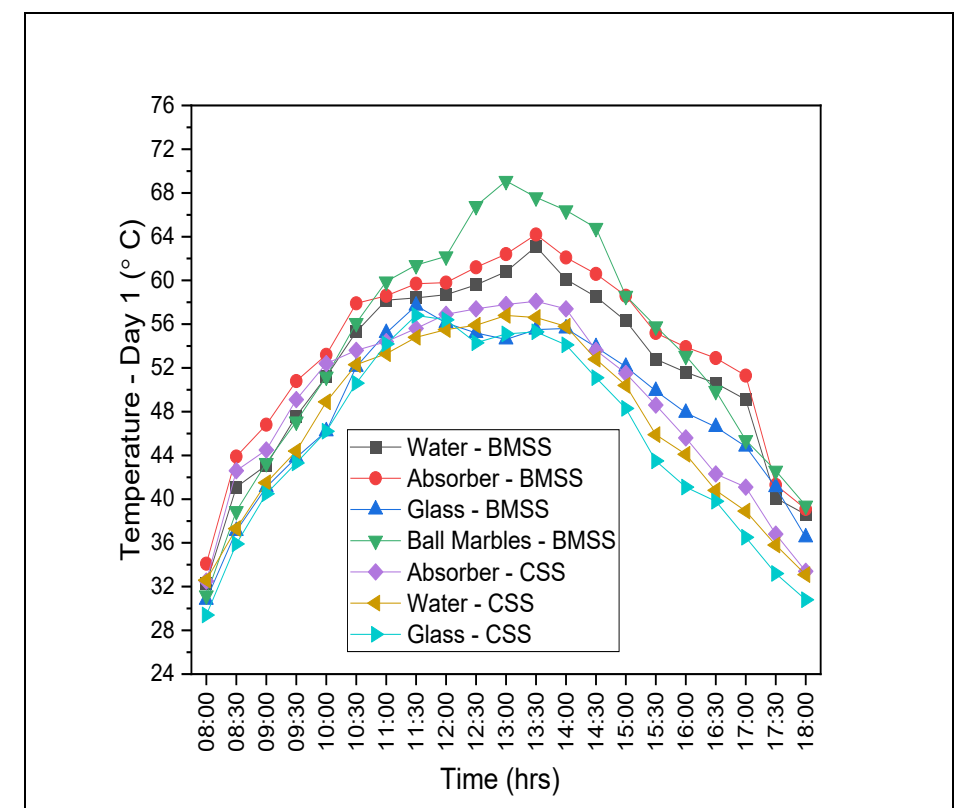

Fig. 5 Variations of different temperatures of both BMSS and CSS on day 1

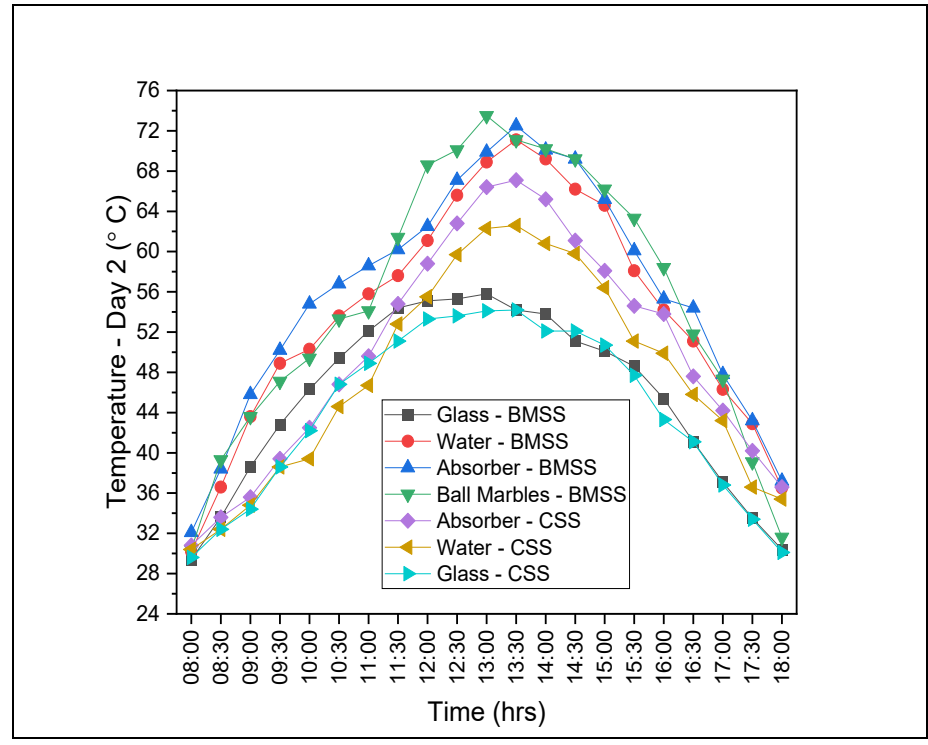

Fig. 6 Variations of different temperatures of both BMSS and CSS on day 2

232 The variations of different temperatures of both BMSS and CSS on day 2 are illustrated in Fig. 6. It was seen that

233 the maximum glass temperatures of BMSS and CSS were about $55.8^{\circ} \mathrm{C}$ and $54.2{ }^{\circ} \mathrm{C}$, respectively and during 234 evening time, it was reduced to about $30.4{ }^{\circ} \mathrm{C}$ and $30.1{ }^{\circ} \mathrm{C}$, respectively. The absorber basin temperatures of 235 BMSS and CSS were augmented during the morning and attained the maximum value of about $72.5{ }^{\circ} \mathrm{C}$ and 67.1

$236{ }^{\circ} \mathrm{C}$, respectively. On day 2 , the basin absorber temperature of BMSS was $9 \%$ higher than CSS. The maximum ball 237 marble temperature was $73.5^{\circ} \mathrm{C}$ in BMSS. Furthermore, the maximum saline water temperature in BMSS and 
238 CSS were observed to be about $71.1^{\circ} \mathrm{C}$ and $65.2{ }^{\circ} \mathrm{C}$, respectively. The observed saline water temperature in BMSS

239 was $14 \%$ higher than CSS. Thus, the incorporation of black-coated ball marbles in the sola still effectively

240 increased the absorber and water temperatures to a greater extent compared to CSS. The rise in the difference

241 between water and glass temperatures ( $\left.\Delta T=T_{\text {water }}-T_{\text {glass }}\right)$ lead to enhanced condensation and hence attained

242 more freshwater yield in the BMSS compared to CSS.

\section{5.2. Effect of Ball Marbles on the system temperatures}

244 The inclusion of sensible energy storage into the solar still significantly improved the temperatures of the system.

245 The ball marbles improved the water and absorber temperature enormously. The ball marbles in the absorber

246 basin played a dominant role in heat transfer between absorber and water during diurnal hours. The ball marbles

247 facilitated the solar still to maintain the highest temperatures of water and absorber from 12.00 P.M to 02.30 P.M

248 when compared to CSS. The upsurge in the water temperatures leads to an enhancement in the evaporation rate

249 in BMSS which caused an improvement in freshwater yield compared to CSS. However, the inclusion of ball

250 marbles into the solar still increased the water and absorber temperatures led to an improvement in the freshwater

251 yield of solar still.

\section{5.3. Productivity}

253 The hourly productivity and cumulative productivity for BMSS and CSS on both testing days are depicted in Fig.

2547 (a) and (b). On day 1, during the morning to afternoon hours (11.00 to 15:00 hours), the hourly productivity of

255 BMSS was significantly improved when compared to CSS. In BMSS, the maximum hourly productivity of about

$256270 \mathrm{ml} / \mathrm{m}^{2}$ was observed during $14: 00$ hours due to the heat energy retained by ball marbles. Similarly, during

257 14:00 hours, improved productivity of about $230 \mathrm{ml} / \mathrm{m}^{2}$ was collected in CSS. In BMSS, the observed maximum

258 productivity is $18 \%$ higher than CSS. On day 2 , the maximum hourly productivity of about $340 \mathrm{ml} / \mathrm{m}^{2}$ was

259 observed in BMSS. In CSS, it was observed to be about $300 \mathrm{ml} / \mathrm{m}^{2}$. which was $14 \%$ lower than BMSS. The

260 productivity of BMSS and CSS on both the testing days is represented as a histogram in Fig. 8. On day 1, it was

261 noticed that the cumulative productivity of BMSS and CSS were about $2150 \mathrm{ml} / \mathrm{m}^{2}$.day and $1750 \mathrm{ml} / \mathrm{m}^{2}$. day,

262 respectively. On day 2, it was observed as $2950 \mathrm{ml} / \mathrm{m}^{2}$.day and $2430 \mathrm{ml} / \mathrm{m}^{2}$. day, respectively in both BMSS and

263 CSS. The cumulative production of the BMSS was $22.8 \%$ and $21.3 \%$ higher than the productivity collected in

264 CSS for day 1 and day 2 , respectively. It was noticed that the average freshwater productivity from the BMSS

265 was $2.7 \mathrm{ml} / \mathrm{m}^{2}$. day, whereas the average freshwater productivity from the CSS was $1.9 \mathrm{~mL} / \mathrm{m}^{2}$. day. 


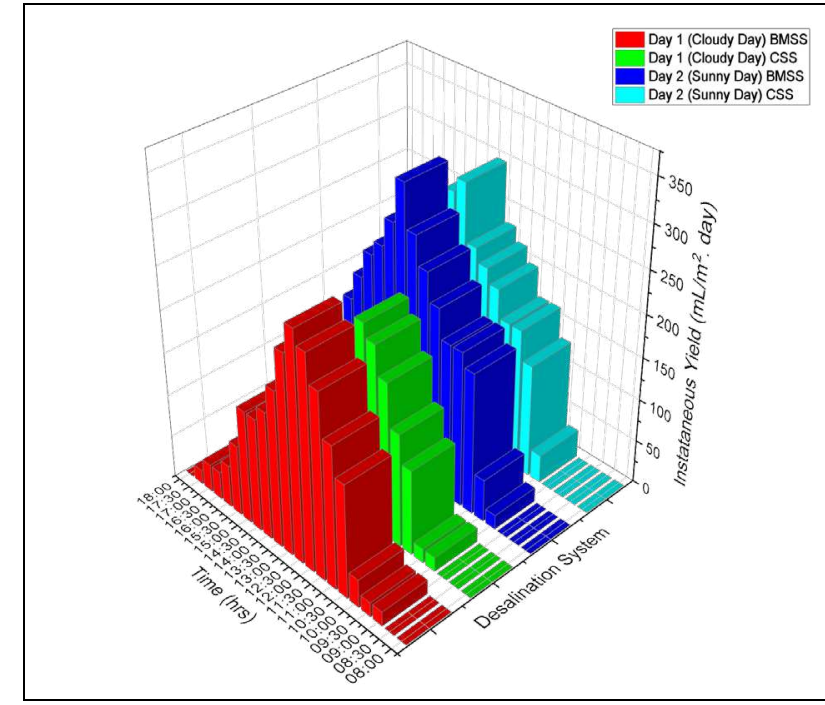

(a)

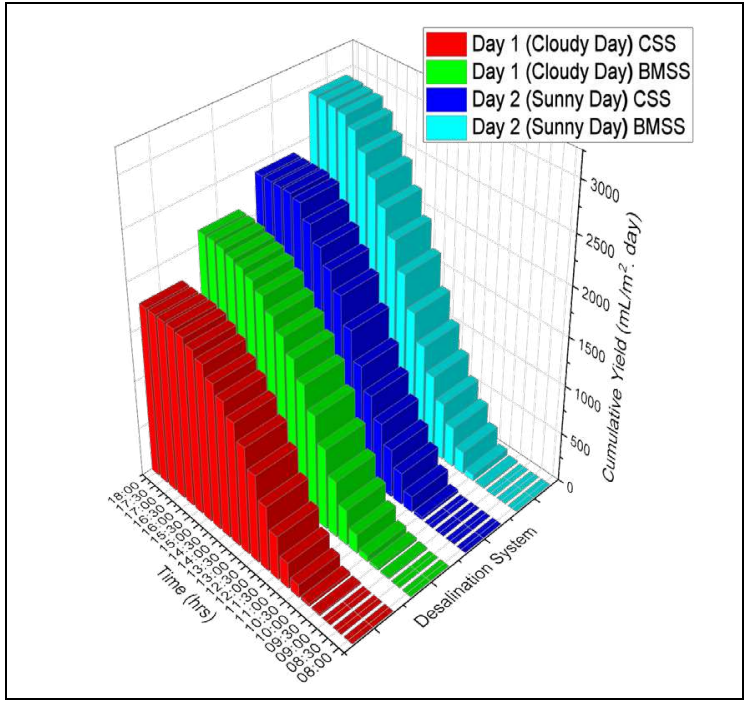

(b)

Fig. 7 Variations of (a) hourly productivity \& (b) Cumulative productivity of BMSS and CSS

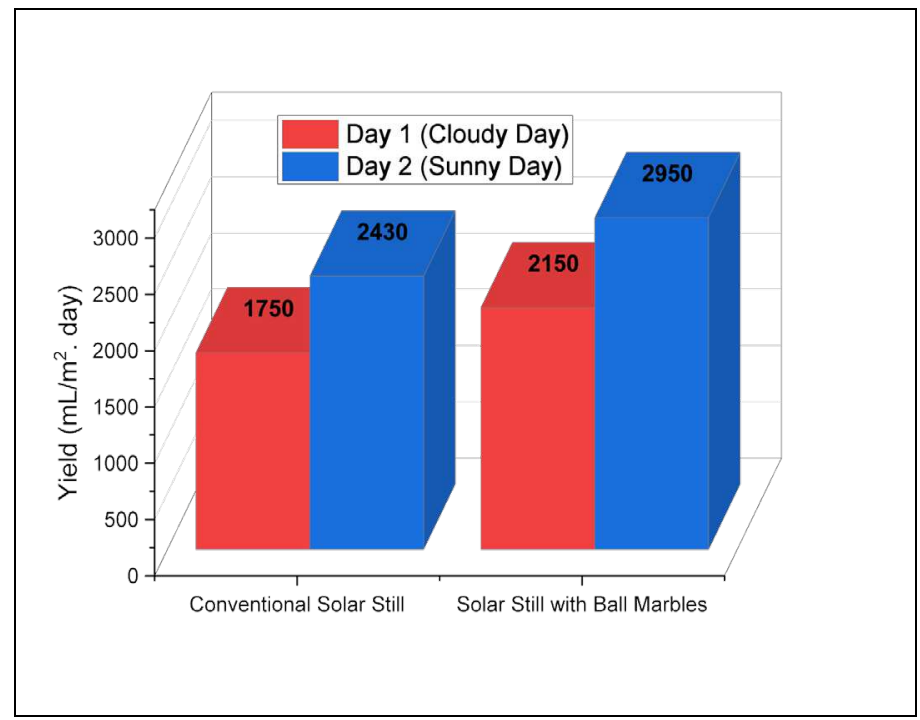

Fig. 8 Histograms representing the final potable water productivity of CSS and BMSS

\section{5.4. Effect of Ball Marbles on the Productivity of Solar Still}

272 The freshwater productivity of the solar still was significantly influenced by the ball marbles as thermal energy storage. The adequate heat-storing capacity of ball marbles allowed the ball marbles to receive and store the

274 incident solar radiation in the form of heat. The stored heat was the key factor for rising the water and absorber temperatures during the peak hours of sunshine. Also, when the sunshine was reduced, the stored heat in the ball marbles got liberated and helped in maintaining the maximum water temperatures for better performance of the solar still. From the above discussion, it was observed that the inclusion of ball marbles into the desalination system significantly enhanced the freshwater productivity from the system. Nevertheless, the incorporation of 
279 ball marbles in the absorber basin substantially improved the freshwater yield by enhancing the heat transfer

280 between the water, absorber and ball marbles.

\section{$281 \quad$ 5.5. Energy Analysis}

282 The thermal efficiency of the single-slope solar stills was evaluated using equation (3). The average thermal

283 efficiency of the BMSS on a cloudy day was $34.9 \%$ whereas the average thermal efficiency of CSS was $25.6 \%$.

284 It was observed that there was an increase of $36.67 \%$ in the average thermal efficiency of BMSS on a cloudy day.

285 Besides, the average thermal efficiency of the BMSS on a sunny day was $47.5 \%$ whereas the average thermal

286 efficiency of CSS was $34.4 \%$. It was observed that there was an increase of $38.11 \%$ in the average thermal

287 efficiency of BMSS on a sunny day. From the above inferences, it was noted that the addition of black-coated

288 ball marbles in the absorber basin as a sensible energy heat storage material significantly increased the

289 performance of single slope solar still by increasing the system temperatures, productivity and energy efficiency.

290 The outcomes of the energy analysis on both testing days is pictorially illustrated in Figure 9 and 10 respectively.

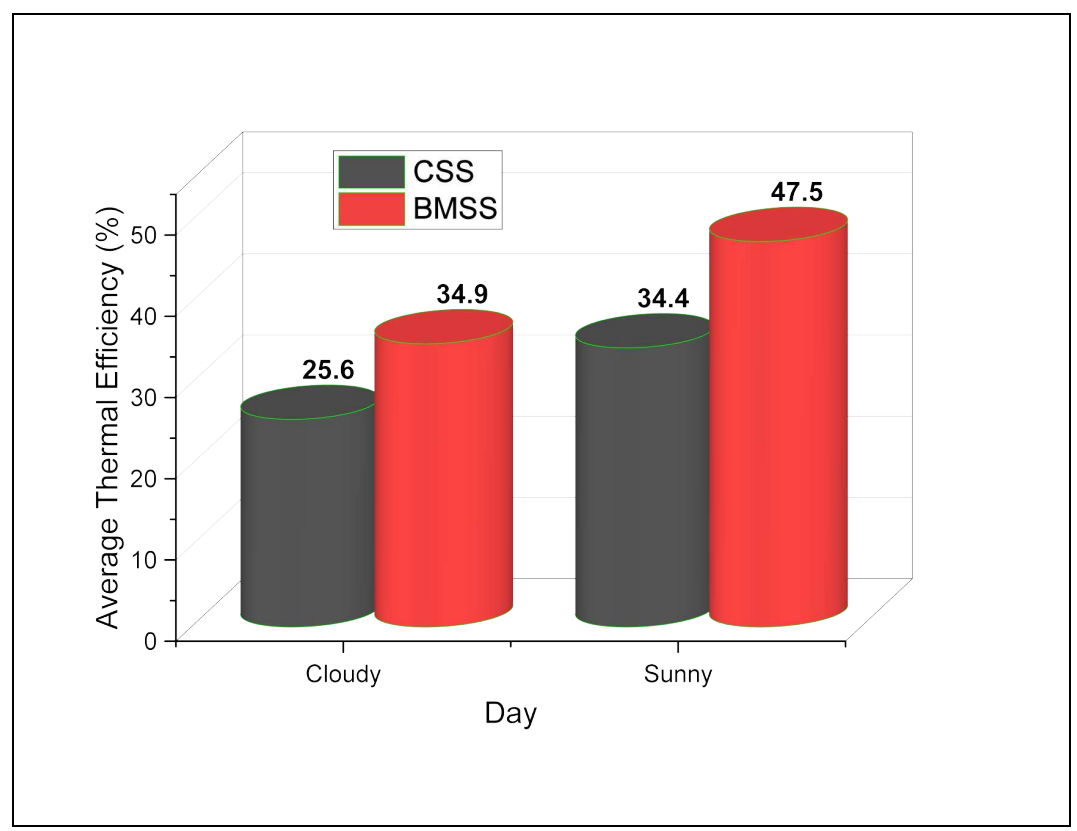




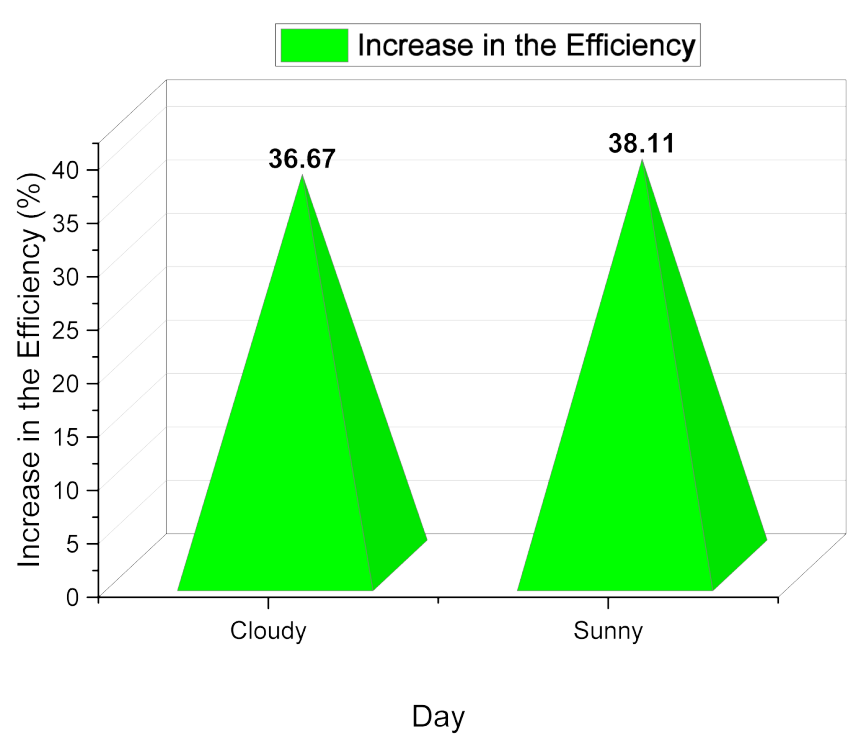

Fig. 9 Increase in the average thermal efficiency of BMSS compared to CSS

\section{5.6. Economic analysis}

296 The capital investment was considered by taking the prices of each part of the desalination system assembly,

297 according to the Indian costs. The capital cost was calculated by considering all the fabrication, maintenance and operation costs. The cost-effectiveness of both the solar stills was estimated using economic analysis and listed in

299 Table 2. From table 2, it was observed that the cost per litre (CPL) of BMSS and CSS was $0.025 \$$ and $0.027 \$$

300 respectively. Besides, the CPL of BMSS is $8 \%$ lower than the CPL estimated in CSS. Furthermore, the PBP of

301 BMSS and CSS was 5.8 months and 6.5 months, respectively. The outcomes of the economic analysis were

302 represented graphically in figure 11 . From the outcomes of the economic analysis, it was observed that the 303 inclusion of ball marbles in the absorber basin is economically viable and sustainable.

Table 2 Economic analysis of BMSS and CSS in both sunny and cloudy days

\begin{tabular}{|c|c|c|}
\hline Parameters & BMSS & CSS \\
\hline CC & $\$ 88$ & $\$ 82$ \\
\hline CRF & 0.177 & 0.177 \\
\hline FAC & 15.57 & 14.51 \\
\hline S & 17.6 & 16.4 \\
\hline SFF & 0.056 & 0.056 \\
\hline ASV & 0.98 & 0.91 \\
\hline AMC & 2.33 & 2.71 \\
\hline
\end{tabular}




\begin{tabular}{|c|c|c|}
\hline AC & 16.92 & 15.77 \\
\hline $\mathrm{P}_{\mathrm{d}}$ & $688.5 \mathrm{~L} / \mathrm{m}^{2}$ & $564.7 \mathrm{~L} / \mathrm{m}^{2}$ \\
\hline CPL & $\$ 0.025$ & $\$ 0.027$ \\
\hline PBP & 5.7 months & 6.5 months \\
\hline
\end{tabular}

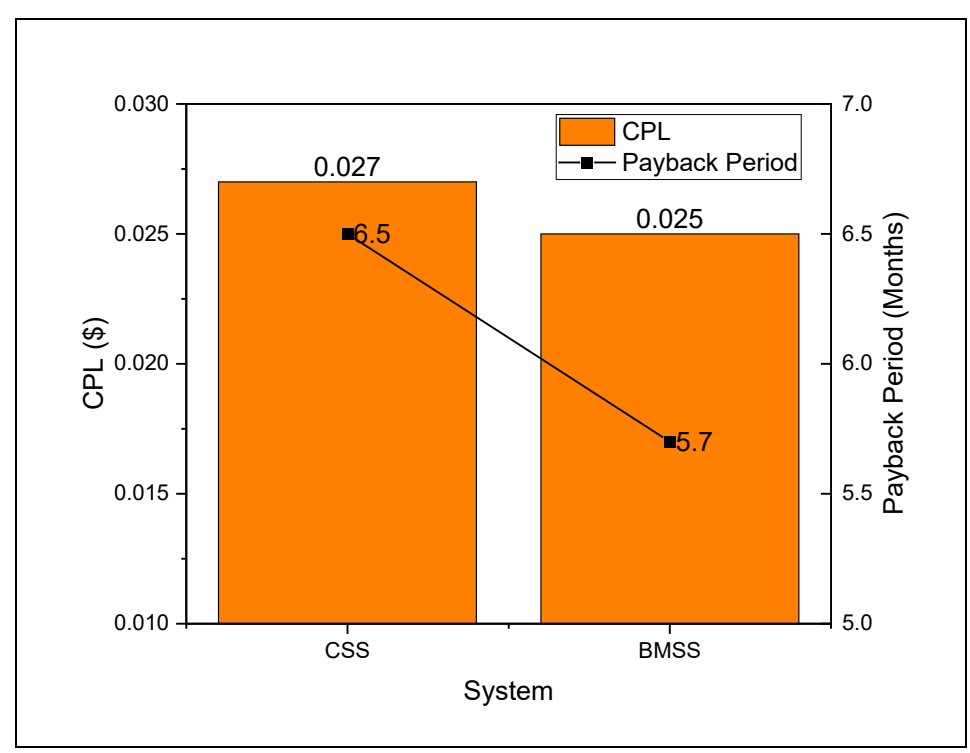

Fig. 10 Representation of outcomes of economic analysis

\section{Conclusion}

The experimentations have been conducted in both the BMSS and CSS to assess the effect of ball marbles on the performance of solar still. The experimental investigation was carried out for two days under the same meteorological conditions of Karaikal city in India during October 2020. The observed major results are given below:

a) The solar still with ball marbles had a better performance compared to CSS.

b) The water temperature was significantly improved using ball marbles in a solar still basin absorber. On day 1 , the BMSS has $12 \%$ improved water temperature when compared to CSS. Similarly, on day 2 , it was improved to about $14 \%$ than CSS. The maximum observed ball marbles temperature in BMSS were $69.9^{\circ} \mathrm{C}$ and $73.5^{\circ} \mathrm{C}$, respectively during sunny and cloudy days.

c) The productivity improvement observed on an hourly basis of BMSS was $18 \%$ and $14 \%$, respectively higher than the CSS on both day 1 and day 2. Besides, the cumulative productivity in BMSS was $22.8 \%$ (day 1 ) and $21.3 \%$ (day 2), respectively higher than the cumulative productivity observed in CSS. The outcomes proved that the usage of ball marbles have enhanced daily productivity considerably. 
d) The average energy efficiency of BMSS and CSS was about $34.9 \%$ and $25.6 \%$ on day 1 respectively. It was observed that there was an increase of $36.7 \%$ in the energy efficiency of BMSS compared to CSS. Besides, the average energy efficiency of BMSS and CSS was about $47.5 \%$ and $38.1 \%$ on day 2 respectively. It was observed that there was an increase of $38.1 \%$ in the energy efficiency of BMSS compared to CSS

e) The economic analysis reported that the PBP of the BMSS and CSS was observed as 5.7 months and 6.5 months, respectively. Similarly, the CPL of BMSS and CSS was about \$ 0.025 and \$ 0.027 , respectively.

It has been concluded from the above results that ball marbles had a better heat transfer rate and raised the system

330 temperatures effectively. Also, the productivity from the BMSS was comparatively better than CSS. The

331 economic analysis also proved that the BMSS was sustainable compared to CSS.

\section{Nomenclature}

$\begin{array}{lll}\text { Abbreviations } & \\ A C & - & \text { Annual cost } \\ A M C & - & \text { Annual maintenance cost } \\ A S V & - & \text { Annual salvage value } \\ B M S S & - & \text { Ball Marbles solar still } \\ C C & - & \text { Capital cost } \\ C P L & - & \text { Cost per litre } \\ C R F & - & \text { Capital recovery factor } \\ C S S & - & \text { Conventional solar still } \\ F A C & - & \text { Fixed annual cost } \\ C S S & - & \text { Conventional solar still } \\ F A C & - & \text { Fixed annual cost } \\ P B P & - & \text { Payback period } \\ S & - & \text { Salvage value } \\ S F F & - & \text { Sinking fund factor } \\ \text { A } & & \end{array}$

\section{Declarations}

334 Ethics approval and consent to participate: Not applicable

335 Consent for Publication: Not applicable 
336 Availability of data and materials: The datasets used and/or analysed during the current study are available from

337 the corresponding author on reasonable request

338 Competing interests: The authors declare that they have no competing interests.

339 Funding: Not applicable

\section{Author Contributions - CRediT author statement}

341 Subbarama Kousik Suraparaju: Conceptualization, Formal analysis, Investigation, Data Curation, Writing -

342 Original Draft.

343 Dhivagar Ramasamy: Conceptualization, Data Curation, Methodology, Writing - original draft.

344 Sendhil Kumar Natarajan: Conceptualization, Validation, Resources, Writing - Review \& Editing, Supervision, 345 Project administration.

\section{$346 \quad$ References}

347 Arjunan T V., Aybar HŞ, Nedunchezhian N (2009) Status of solar desalination in India. Renewable and

348 Sustainable Energy Reviews 13:2408-2418. https://doi.org/10.1016/j.rser.2009.03.006

349 Arunkumar T, Denkenberger D, Ahsan A, Jayaprakash R (2013) The augmentation of distillate yield by using concentrator coupled solar still with phase change material. Desalination 314:189-192. https://doi.org/10.1016/j.desal.2013.01.018

Aybar HS, Assefi H (2009) A review and comparison of solar distillation: Direct and indirect type systems. Desalination and Water Treatment 10:321-331. https://doi.org/10.5004/dwt.2009.931

Bait O, Si-Ameur M (2018) Enhanced heat and mass transfer in solar stills using nanofluids: A review. Solar Energy 170:694-722. https://doi.org/10.1016/j.solener.2018.06.020

Chamkha AJ, Rufuss DDW, Kabeel AE, et al (2020) Augmenting the potable water produced from single slope solar still using CNT-doped paraffin wax as energy storage: an experimental approach. Journal of the Brazilian Society of Mechanical Sciences and Engineering 42:1-10. https://doi.org/10.1007/s40430-02002703-w

Dashtban M, Tabrizi FF (2011) Thermal analysis of a weir-type cascade solar still integrated with PCM storage. Desalination 279:415-422. https://doi.org/10.1016/j.desal.2011.06.044 analysis of gravel coarse aggregate sensible heat storage-assisted single-slope solar still. Journal of Thermal Analysis and Calorimetry. https://doi.org/10.1007/s10973-020-09766-w 
Dhivagar R, Sundararaj S (2018) A Review on Methods of Productivity Improvement in Solar Desalination. Applied Mechanics and Materials 877:414-429. https://doi.org/10.4028/www.scientific.net/amm.877.414

Dhivagar R, Sundararaj S (2019) Thermodynamic and water analysis on augmentation of a solar still with copper tube heat exchanger in coarse aggregate. Journal of Thermal Analysis and Calorimetry 136:89-99. https://doi.org/10.1007/s10973-018-7746-1

Dsilva Winfred Rufuss D, Iniyan S, Suganthi L, Davies PA (2016) Solar stills: A comprehensive review of designs, performance and material advances. Renewable and Sustainable Energy Reviews 63:464-496. https://doi.org/10.1016/j.rser.2016.05.068

Dumka P, Chauhan R, Mishra DR (2020) Experimental and theoretical evaluation of a conventional solar still augmented with jute covered plastic balls. Journal of Energy Storage 32:101874. https://doi.org/10.1016/j.est.2020.101874

Dumka P, Sharma A, Kushwah Y, et al (2019) Performance evaluation of single slope solar still augmented with sand-filled cotton bags. Journal of Energy Storage 25:100888. https://doi.org/10.1016/j.est.2019.100888

Durkaieswaran P, Murugavel KK (2015) Various special designs of single basin passive solar still - A review. Renewable and Sustainable Energy Reviews 49:1048-1060. https://doi.org/10.1016/j.rser.2015.04.111

El-Sebaii AA, El-Bialy E (2015) Advanced designs of solar desalination systems: A review. Renewable and Sustainable Energy Reviews 49:1198-1212. https://doi.org/10.1016/j.rser.2015.04.161

Esfahani JA, Rahbar N, Lavvaf M (2011) Utilization of thermoelectric cooling in a portable active solar still An experimental study on winter days. Desalination 269:198-205. https://doi.org/10.1016/j.desal.2010.10.062

Fathy M, Hassan H, Salem Ahmed M (2018) Experimental study on the effect of coupling parabolic trough

Gad HE, Shams El-Din S, Hussien AA, Ramzy K (2015) Thermal analysis of a conical solar still performance: collector with double slope solar still on its performance. Solar Energy 163:54-61. An experimental study. Solar Energy 122:900-909. https://doi.org/10.1016/j.solener.2015.10.016

391 Kabeel AE, Abdelgaied M (2017) Observational study of modified solar still coupled with oil serpentine loop from cylindrical parabolic concentrator and phase changing material under basin. Solar Energy 144:7178. https://doi.org/10.1016/j.solener.2017.01.007 
Kabeel AE, El-Agouz SA, Sathyamurthy R, Arunkumar T (2018a) Augmenting the productivity of solar still using jute cloth knitted with sand heat energy storage. Desalination 443:122-129. https://doi.org/10.1016/j.desal.2018.05.026

Kabeel AE, El-Samadony YAF, El-Maghlany WM (2018b) Comparative study on the solar still performance utilizing different PCM. Desalination 432:89-96. https://doi.org/10.1016/j.desal.2018.01.016

Khalifa AJN, Hamood AM (2009) On the verification of the effect of water depth on the performance of basin type solar stills. Solar Energy 83:1312-1321. https://doi.org/10.1016/j.solener.2009.04.006

Kumar S, Tiwari GN (2009) Estimation of internal heat transfer coefficients of a hybrid (PV/T) active solar still. Solar Energy 83:1656-1667. https://doi.org/10.1016/j.solener.2009.06.002

Manchanda H, Kumar M (2015) A comprehensive decade review and analysis on designs and performance parameters of passive solar still. Renewables: Wind, Water, and Solar 2:. https://doi.org/10.1186/s40807015-0019-8

Manokar AM, Winston DP, Mondol JD, et al (2018) Comparative study of an inclined solar panel basin solar still in passive and active mode. Solar Energy 169:206-216. https://doi.org/10.1016/j.solener.2018.04.060

Muthu Manokar A, Kalidasa Murugavel K, Esakkimuthu G (2014) Different parameters affecting the rate of evaporation and condensation on passive solar still - A review. Renewable and Sustainable Energy Reviews 38:309-322. https://doi.org/10.1016/j.rser.2014.05.092

Panchal H, Patel P, Patel N, Thakkar H (2017) Performance analysis of solar still with different energyabsorbing materials. International Journal of Ambient Energy 38:224-228. https://doi.org/10.1080/01430750.2015.1086683

Patel SK, Kumar B, Pal P, et al (2020) Production of potable water from Gomti River by using modified double slope solar still with external mounted reflectors. Solar Energy 209:576-589. https://doi.org/10.1016/j.solener.2020.09.036

Raj G, Prabhansu D, Kumar R, et al (2020) Experimental study of solar still augmented with low-cost energy absorbing and releasing materials. Energy Sources, Part A: Recovery, Utilization and Environmental Effects 42:56-65. https://doi.org/10.1080/15567036.2019.1587054

Sahota L, Tiwari GN (2016) Effect of Al2O3 nanoparticles on the performance of passive double slope solar still. Solar Energy 130:260-272. https://doi.org/10.1016/j.solener.2016.02.018 
Sakthivel TG, Arjunan T V. (2019) Thermodynamic performance comparison of single slope solar stills with and without cotton cloth energy storage medium. Journal of Thermal Analysis and Calorimetry 137:351360. https://doi.org/10.1007/s10973-018-7909-0

430 Sathish Kumar TR, Jegadheeswaran S, Chandramohan P (2019) Performance investigation on fin type solar still with paraffin wax as energy storage media. Journal of Thermal Analysis and Calorimetry 136:101-112. https://doi.org/10.1007/s10973-018-7882-7

Sathyamurthy R, El-Agouz E (2019) Experimental analysis and exergy efficiency of a conventional solar still with Fresnel lens and energy storage material. Heat Transfer - Asian Research 48:885-895. https://doi.org/10.1002/htj.21412

Selvaraj K, Natarajan A (2018) Factors influencing the performance and productivity of solar stills - A review. Desalination 435:181-187. https://doi.org/10.1016/j.desal.2017.09.031

Shalaby SM, El-Bialy E, El-Sebaii AA (2016) An experimental investigation of a v-corrugated absorber singlebasin solar still using PCM. Desalination 398:247-255. https://doi.org/10.1016/j.desal.2016.07.042

Sharon H, Reddy KS (2015) A review of solar energy driven desalination technologies. Renewable and Sustainable Energy Reviews 41:1080-1118. https://doi.org/10.1016/j.rser.2014.09.002

Singh DB, Tiwari GN, Al-Helal IM, et al (2016) Effect of energy matrices on life cycle cost analysis of passive solar stills. Solar Energy 134:9-22. https://doi.org/10.1016/j.solener.2016.04.039

Singh HN, Tiwari GN (2004) Monthly performance of passive and active solar stills for different Indian climatic conditions. Desalination 168:145-150. https://doi.org/10.1016/j.desal.2004.06.180

Suraparaju SK, Natarajan SK (2020) Performance analysis of single slope solar desalination setup with natural fibre. Desalination and Water Treatment 193:64-71. https://doi.org/10.5004/dwt.2020.25679

Tanaka H, Nakatake Y (2009) Increase in distillate productivity by inclining the flat plate external reflector of a tilted-wick solar still in winter. Solar Energy 83:785-789. https://doi.org/10.1016/j.solener.2008.12.001 
456 Vigneswaran VS, Kumaresan G, Dinakar B V., et al (2019) Augmenting the productivity of solar still using 457 multiple PCMs as heat energy storage. Journal of Energy Storage 26:101019.

$458 \quad$ https://doi.org/10.1016/j.est.2019.101019

459 Winfred Rufuss DD, Iniyan S, Suganthi L, Pa D (2017) Nanoparticles Enhanced Phase Change Material $460 \quad(\mathrm{NPCM})$ as Heat Storage in Solar Still Application for Productivity Enhancement. Energy Procedia $461 \quad$ 141:45-49. https://doi.org/10.1016/j.egypro.2017.11.009

462 Yadav S, Sudhakar K (2015) Different domestic designs of solar stills: A review. Renewable and Sustainable 463 Energy Reviews 47:718-731. https://doi.org/10.1016/j.rser.2015.03.064

464 Ziabari FB, Sharak AZ, Moghadam H, Tabrizi FF (2013) Theoretical and experimental study of cascade solar stills. Solar Energy 90:205-211. https://doi.org/10.1016/j.solener.2012.12.019 


\section{Figures}

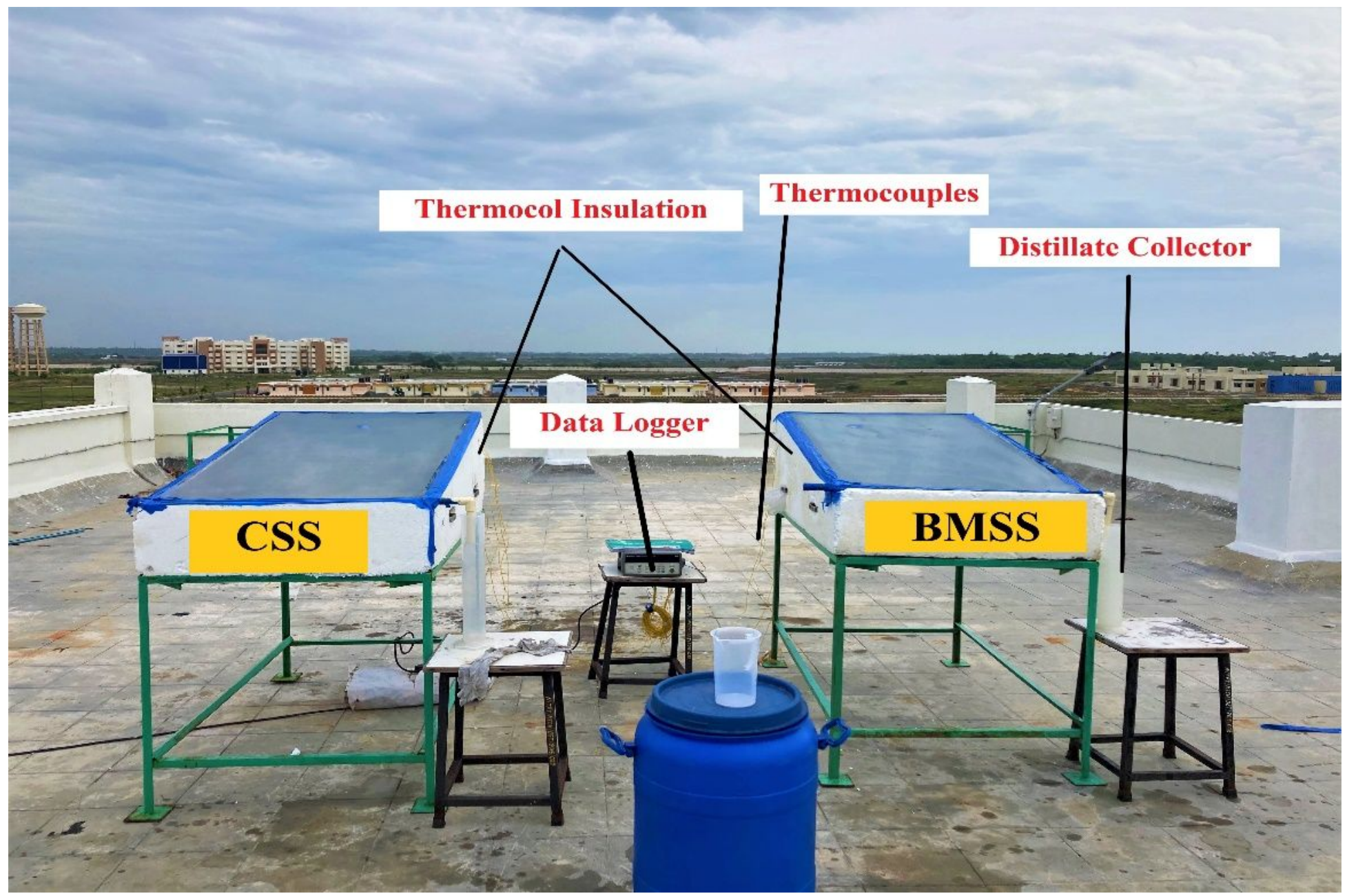

Figure 1

Photographs of BMSS and CSS 


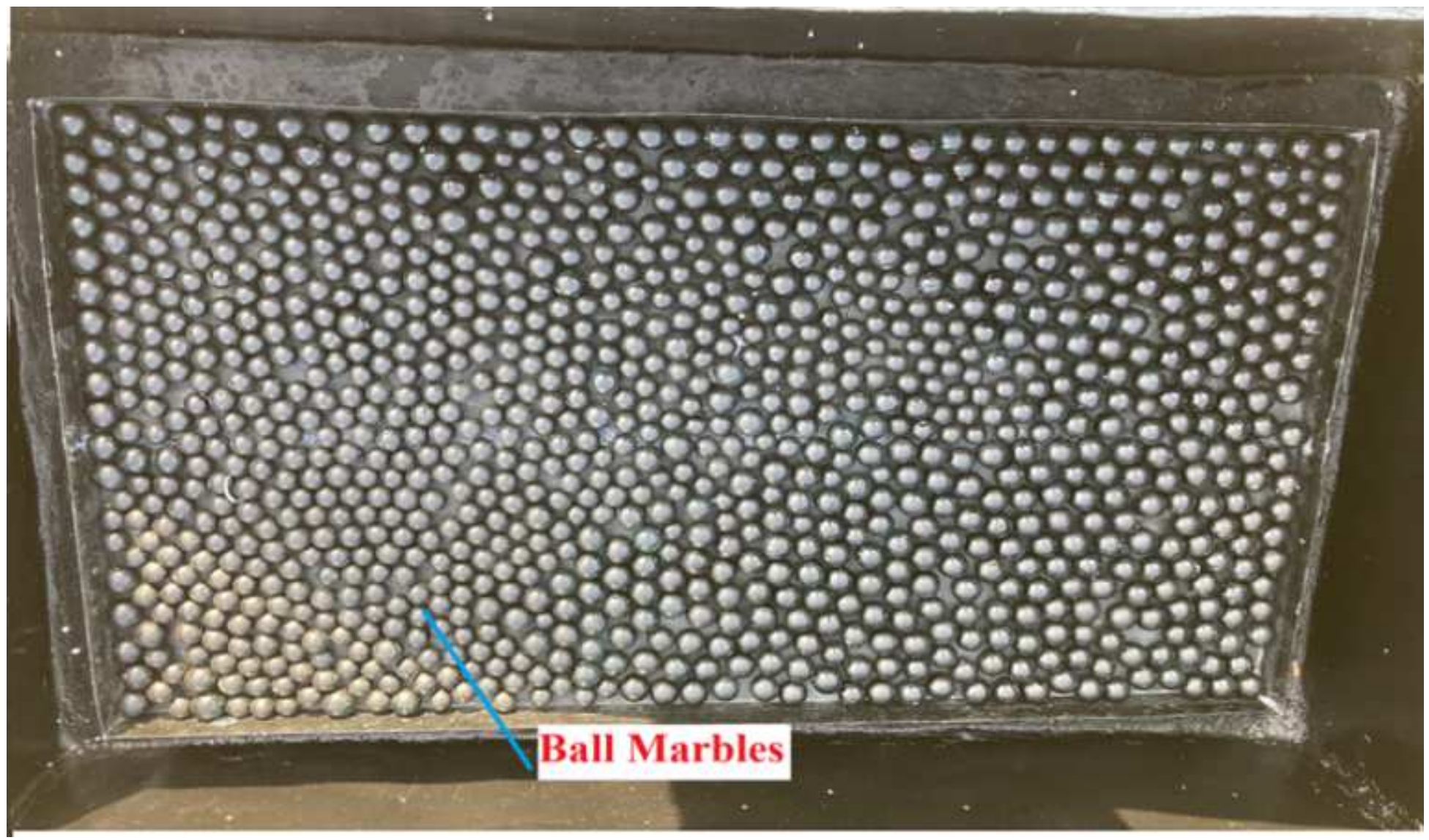

Figure 2

Arrangement of black coated ball marbles in the solar still 


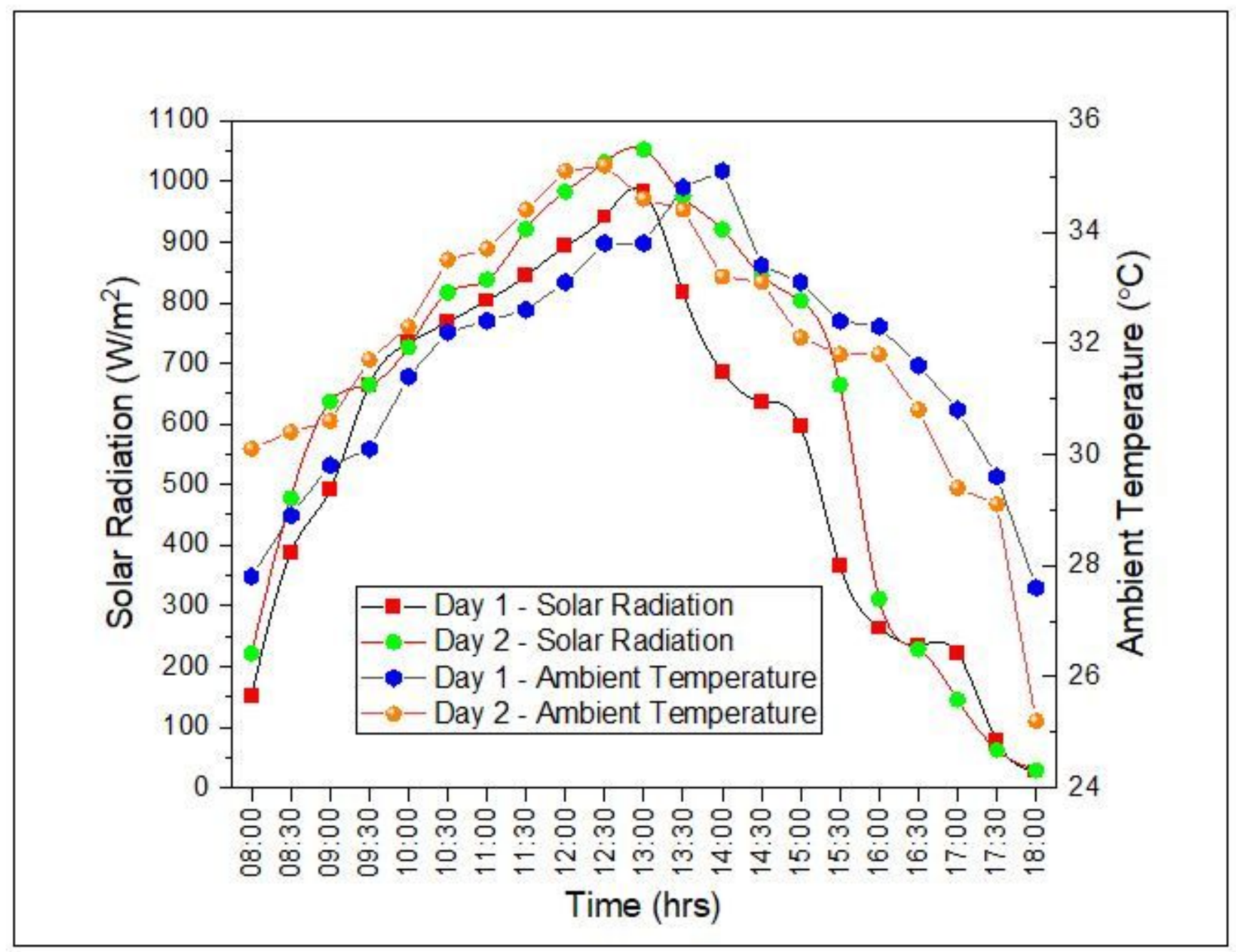

Figure 3

Variations of solar radiation and ambient temperature with time 


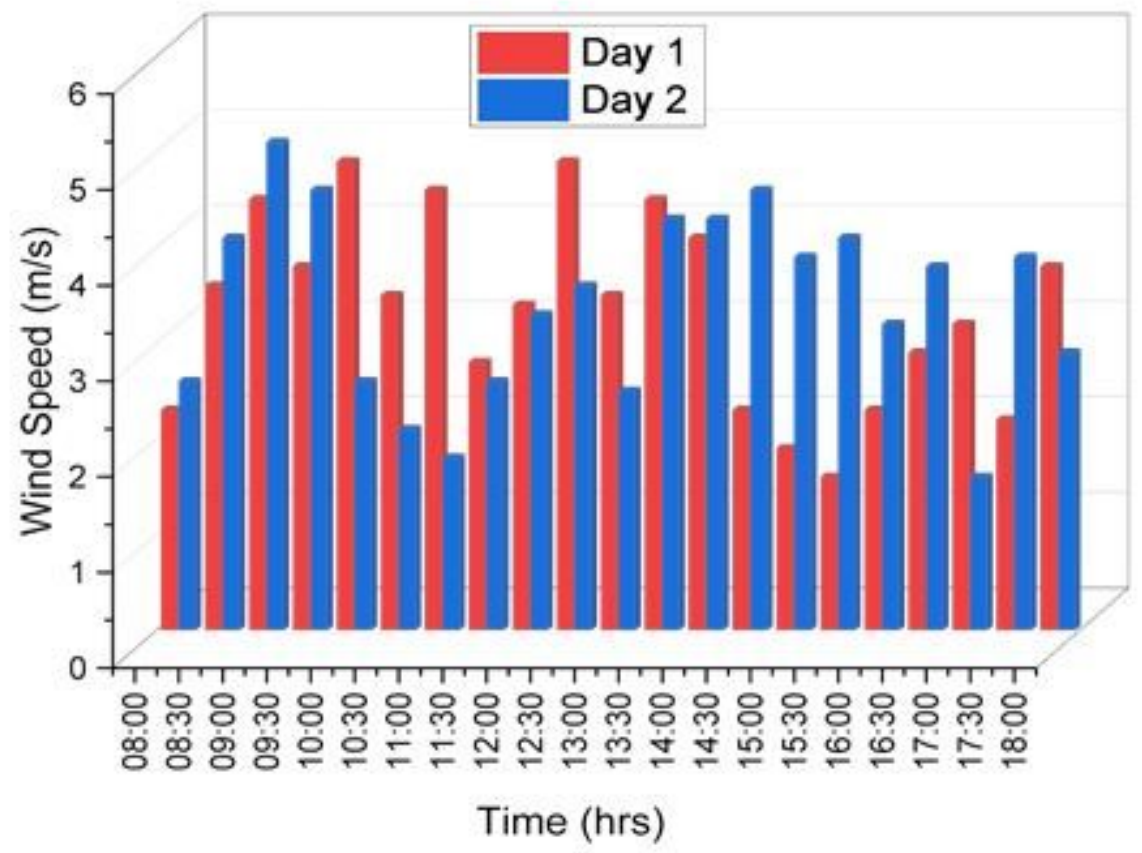

Figure 4

Variations of wind velocity with time 


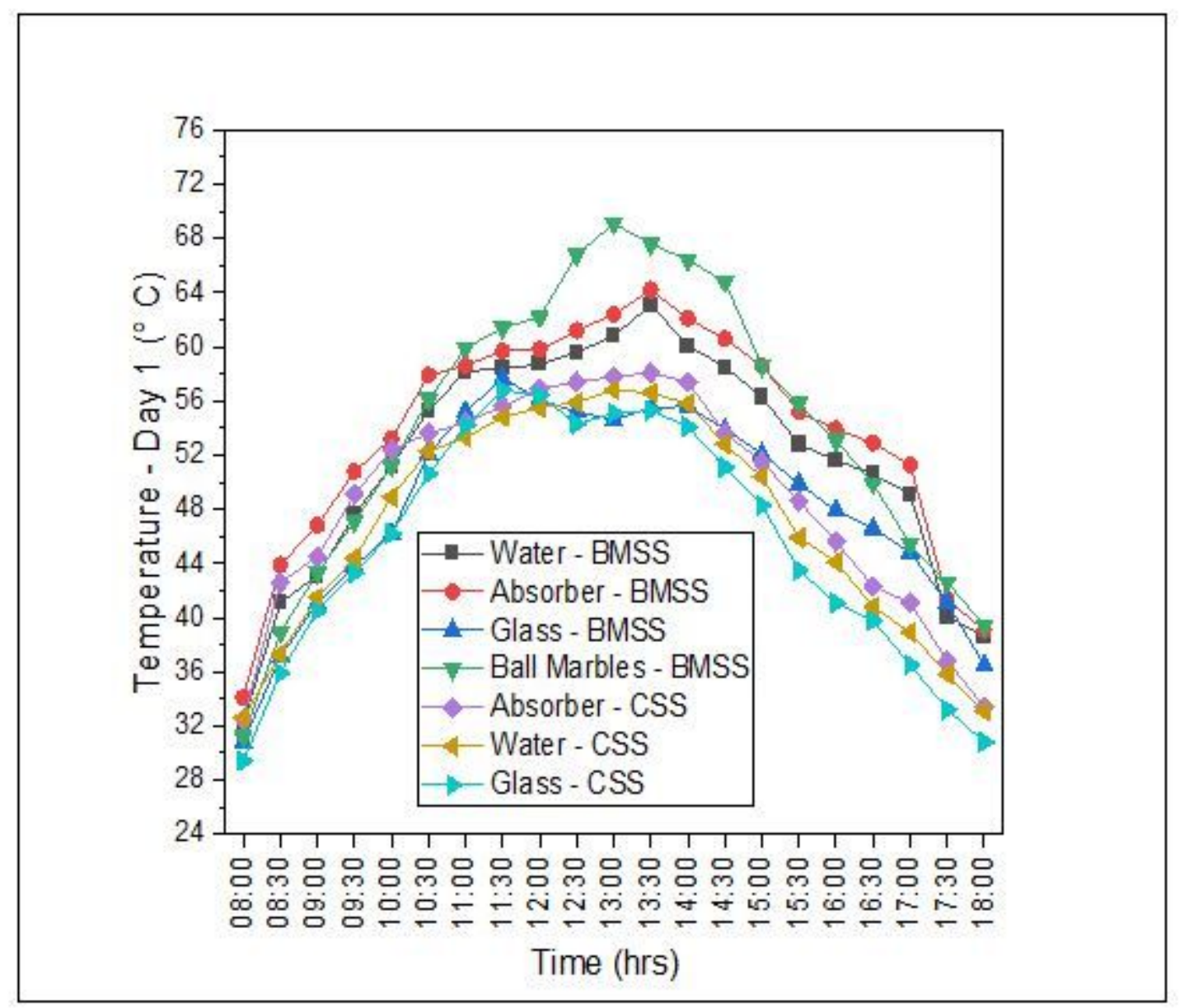

\section{Figure 5}

Variations of different temperatures of both BMSS and CSS on day 1 


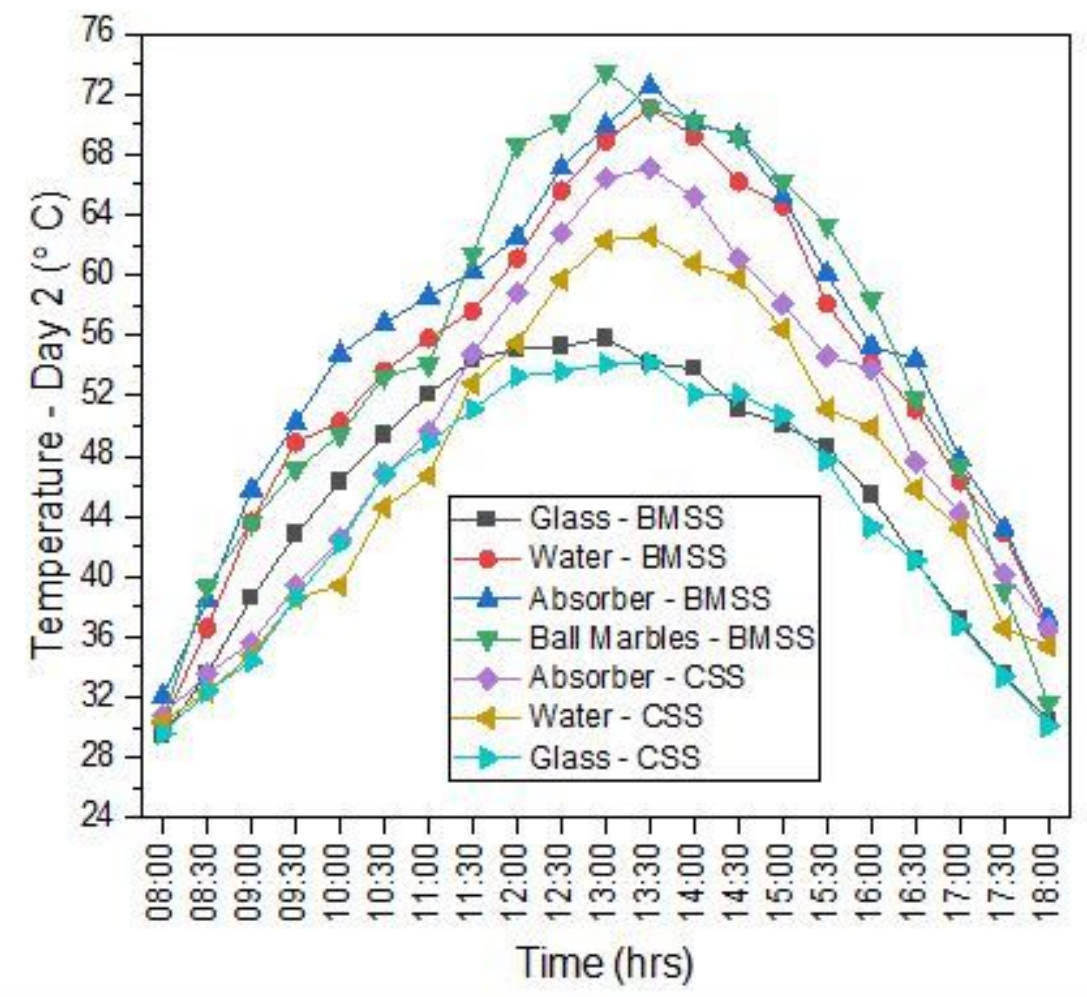

Figure 6

Variations of different temperatures of both BMSS and CSS on day 2

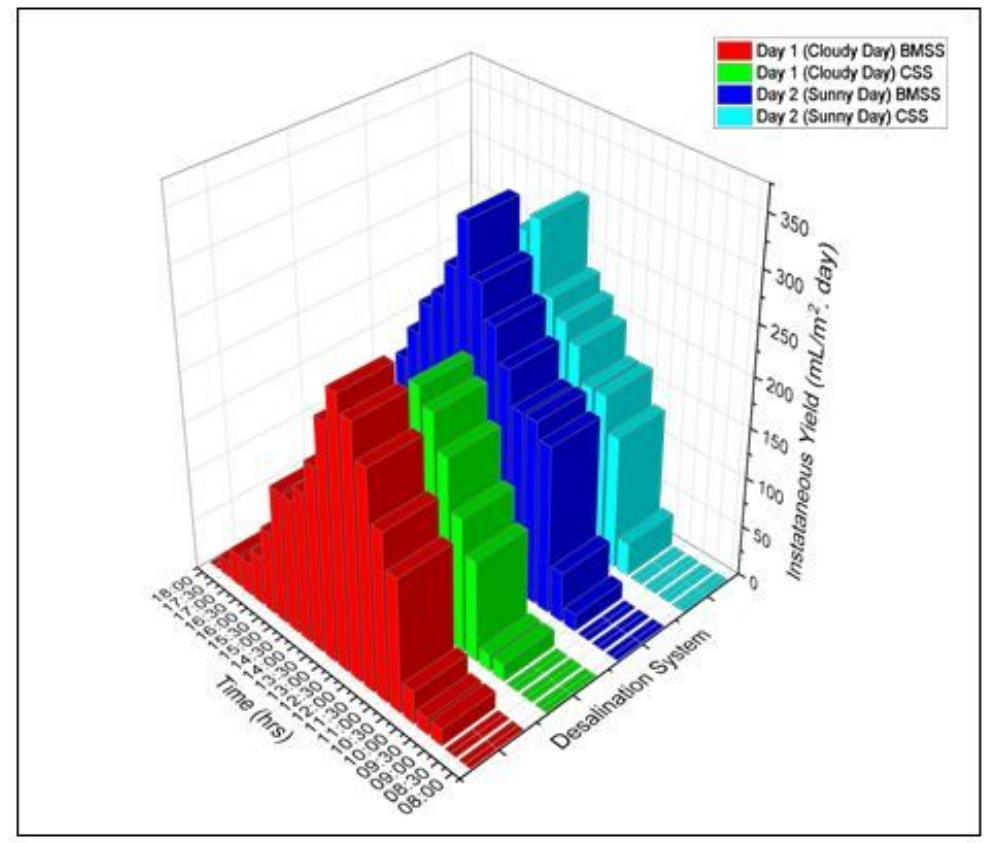

(a)

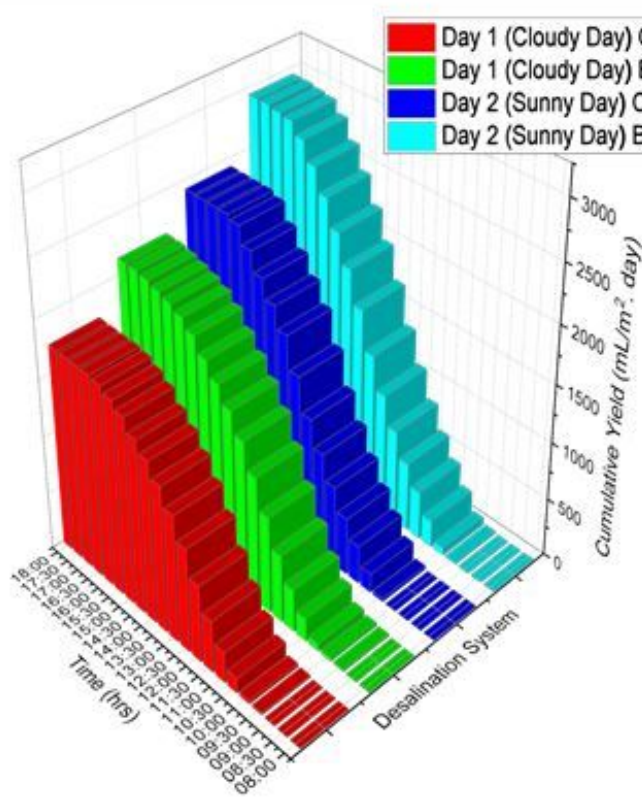

(b)

Figure 7 
Variations of (a) hourly productivity \& (b) Cumulative productivity of BMSS and CSS

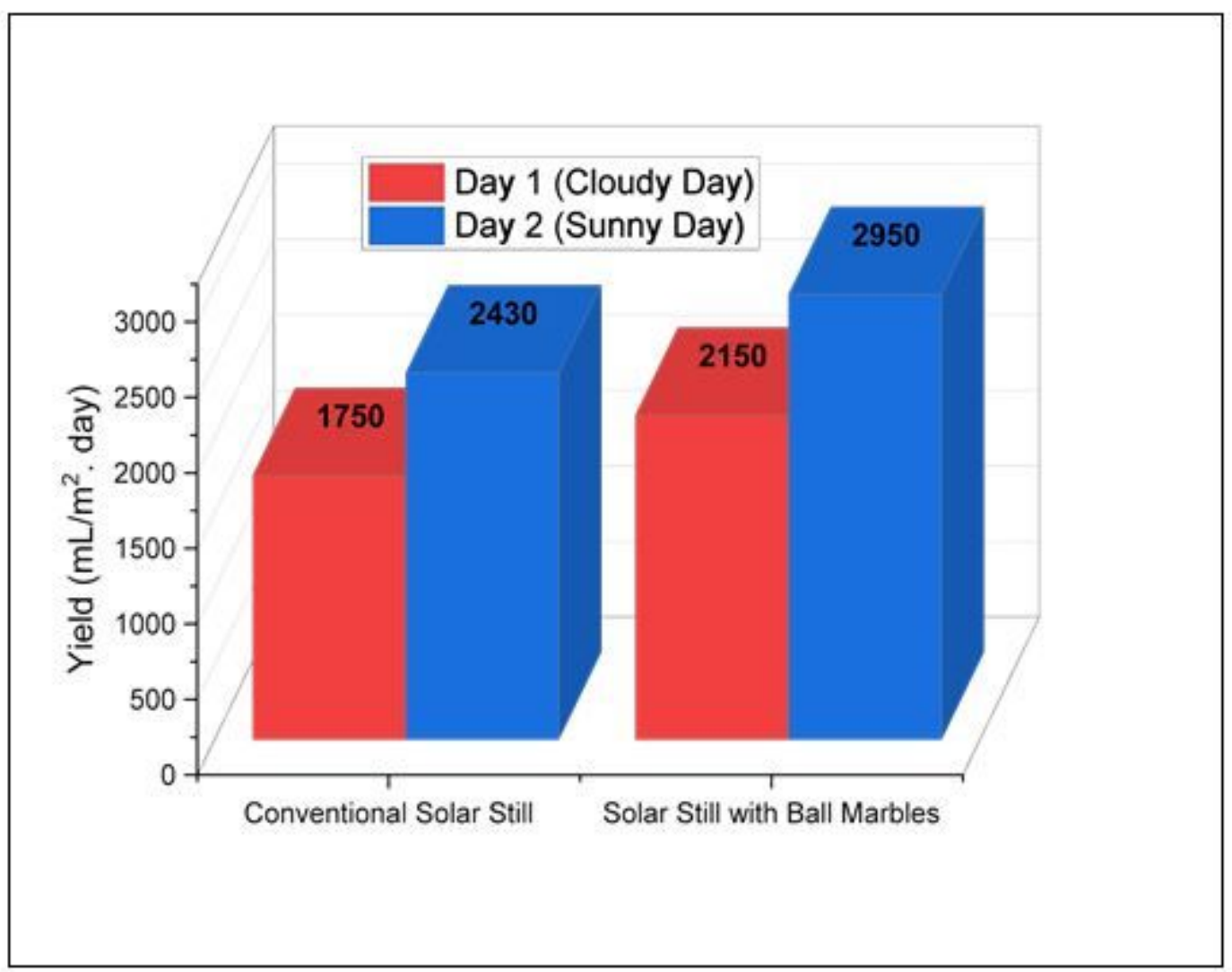

Figure 8

Histograms representing the final potable water productivity of CSS and BMSS 


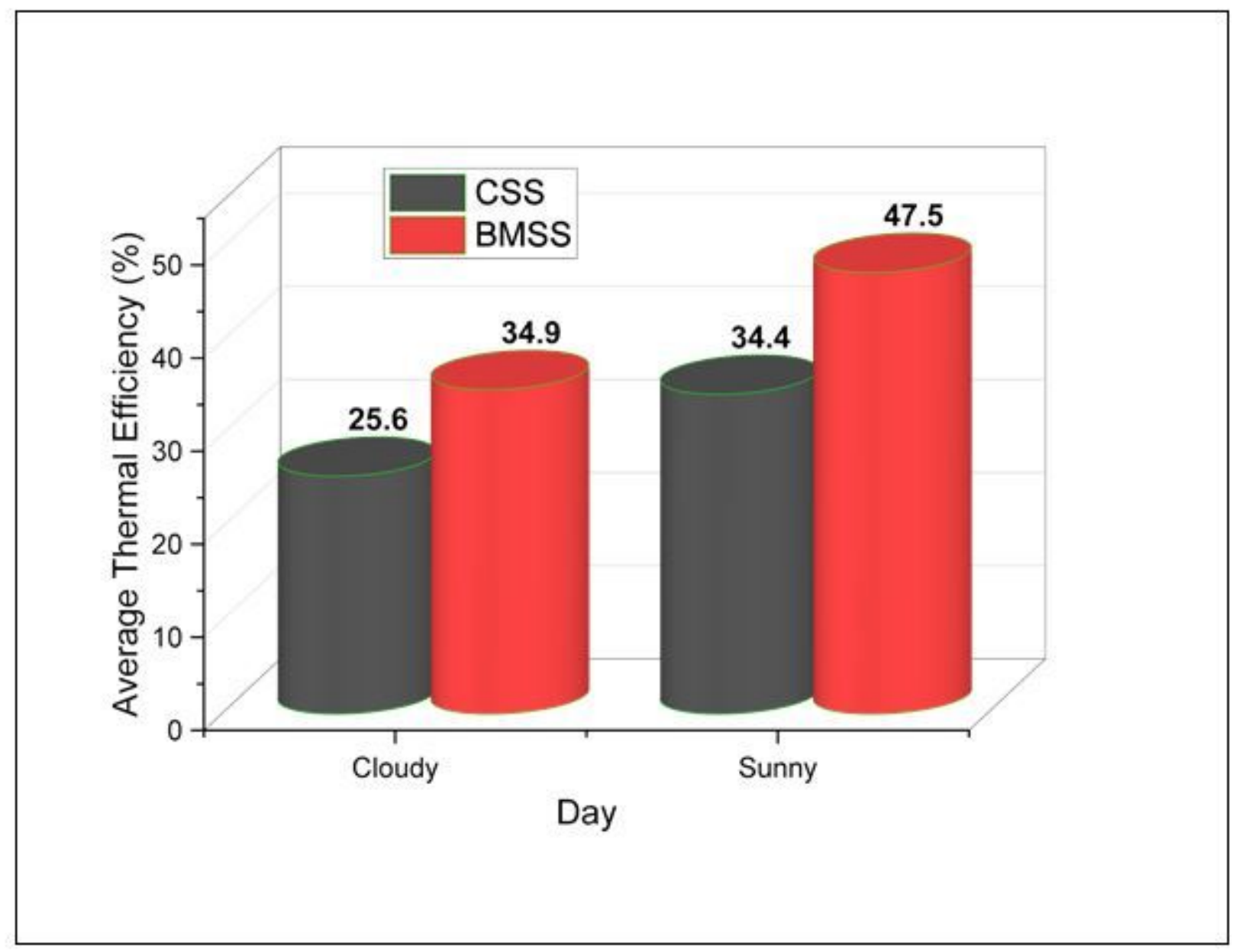

Figure 9

Average thermal efficiencies of BMSS and CSS on day $1 \& 2$ 


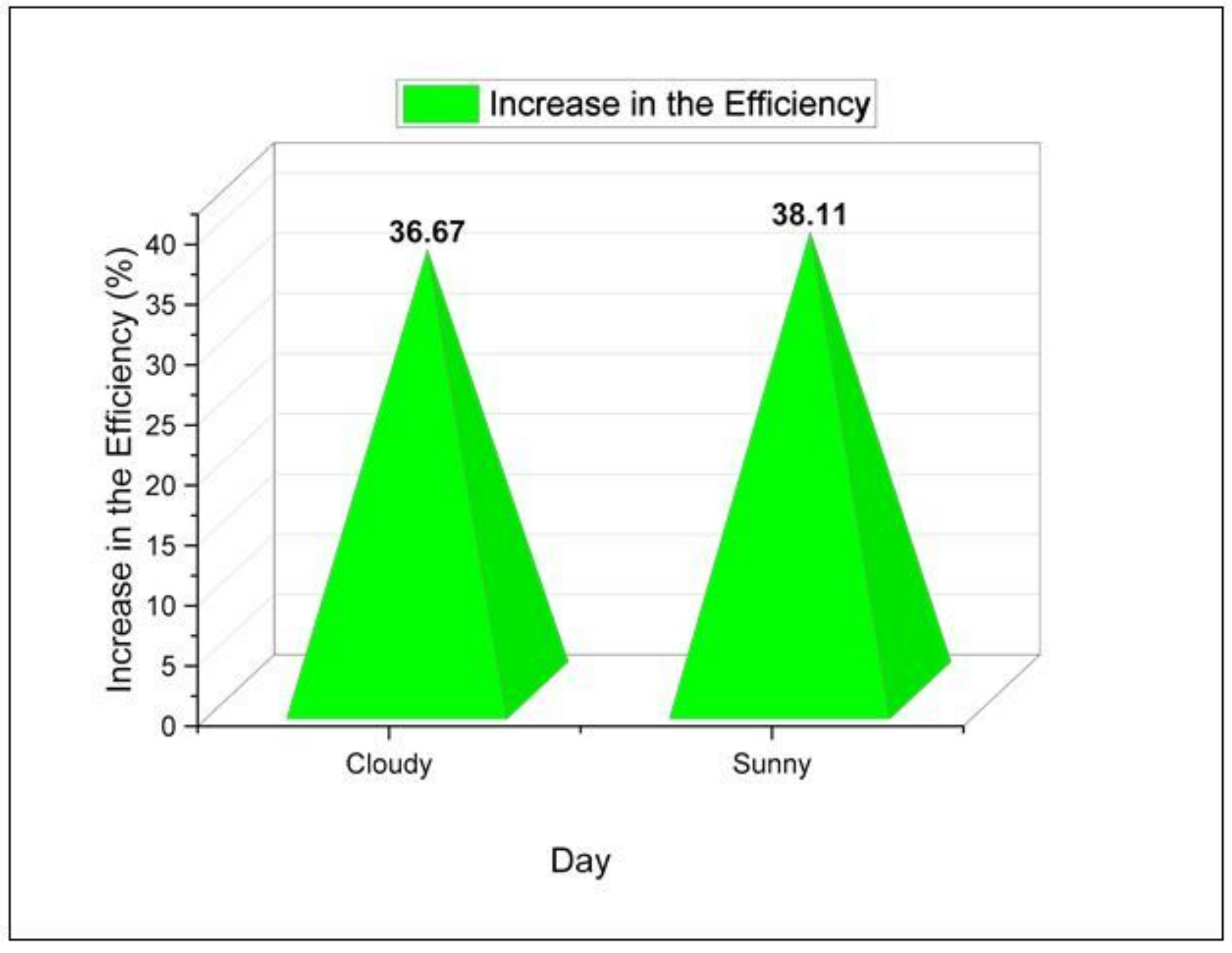

Figure 10

Increase in the average thermal efficiency of BMSS compared to CSS 


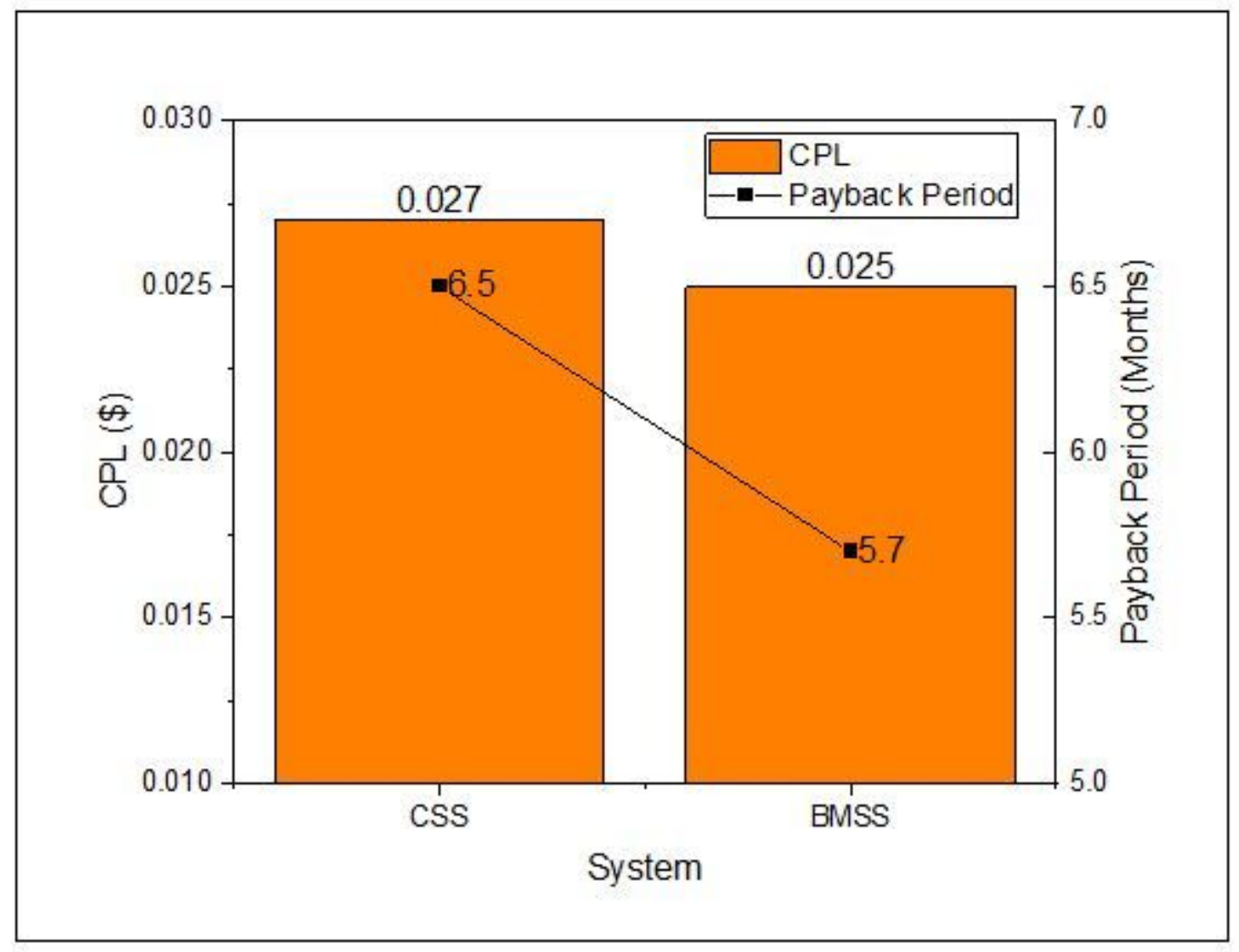

Figure 11

Representation of outcomes of economic analysis

\section{Supplementary Files}

This is a list of supplementary files associated with this preprint. Click to download.

- Data.xlsx 